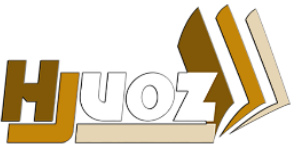

hjuoz.uoz.edu.krd p-ISSN: 2410-7557 e-ISSN: 2518-5128
كَّوارا زانستيّن مروّقايهتى يا زانكوّيا زاخوّ

مجلة العلوم الانسانية لجامعة زاخو

Humanities Journal of University of Zakho (HJUOZ)

Vol. 5, No. 4, pp. 1020-1032, December-2017

\title{
يهود كُردستان والأصول المذهبية ليهود مدينة زاخو
}

\author{
خطاب إسماعيل أحمد و توفيق رشيد يوسف \\ قسم التاريخ، فاكولتي العلوم الإنسانية، جامعة زاخو، اقليم كوردستان - العراق.
}

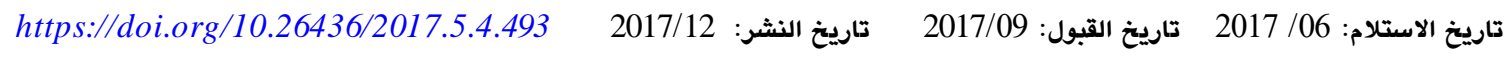

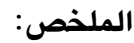

يهدف هذا البحث إلى دراسة تاريخ الوجود اليهودي في كُرستان عامةً، ودراسة الأصول المذهبية ليهود مدينة زاخو خاصةً، من خلال

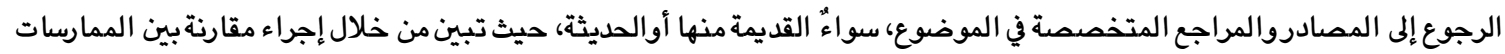

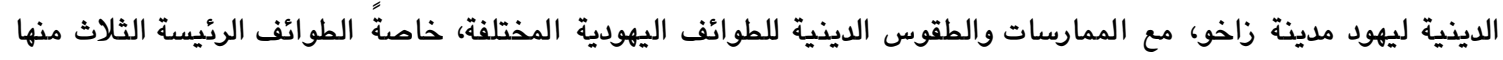

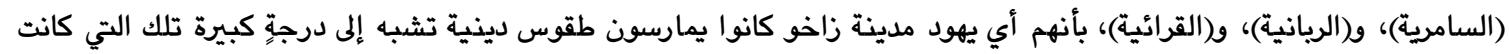

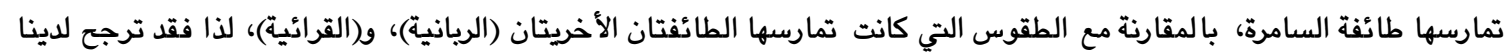

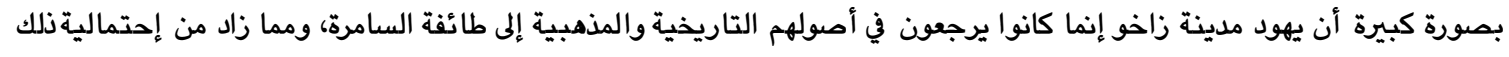

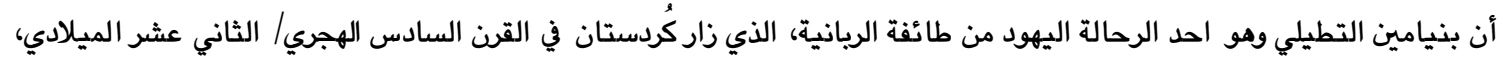

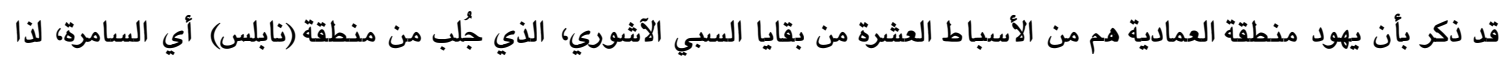

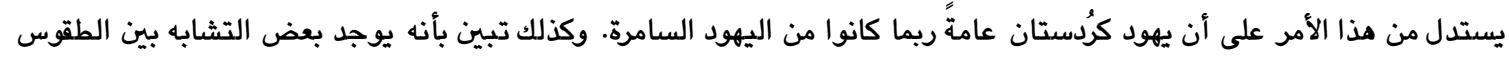

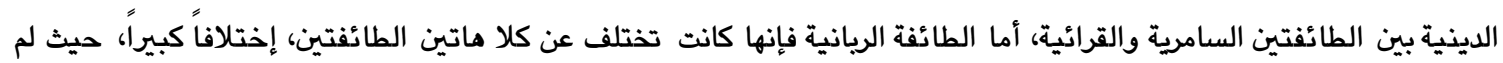
يلاحظ وجود يهود ينتمون إليها في مدينة زاخو. الكلمات الدالة: اليهود، كُردستان، المذهبية، مدينة زاخو.

مما زاد من صعوية الجزم بالأصول المذهبية لمدينة زاخو خاصةً ويهود كُردستان بصورة عامة.

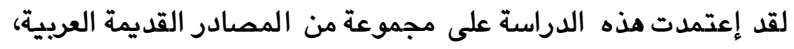

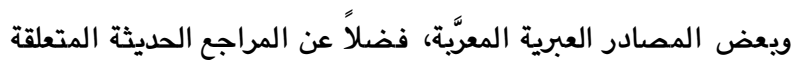

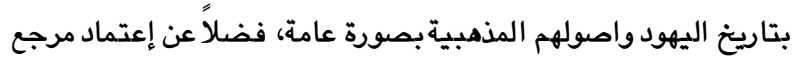

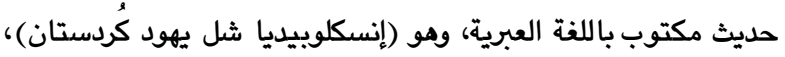

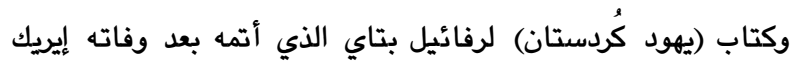

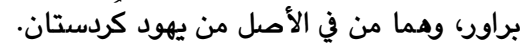

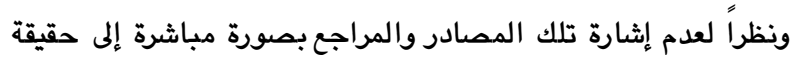

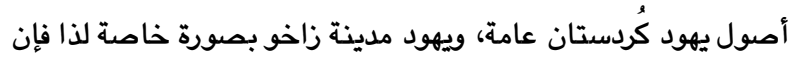

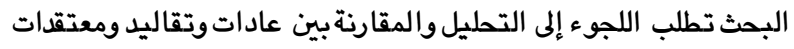
وطقوس كل طائفة من تلك الطاوائف الثلاث، حيث تبين بأن يهود مدينة زاخو كانوا أقرب إلى مذهب السامرة من القرائية والريانية، وذلك لتشائ تلثابه

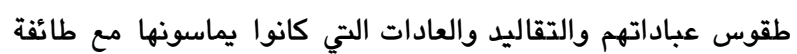
السامرة، فضلاً عن وجود بعض إثارات من بعض الرحالة اليهود

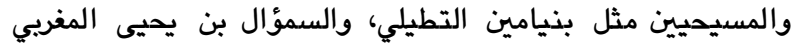

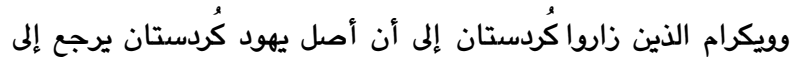

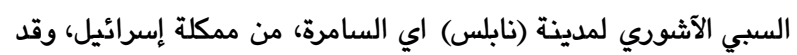

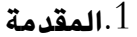

يرجع تاريخ الوجود اليهودي في كُردستان بصورة عامة بطوائفهم الثلاث

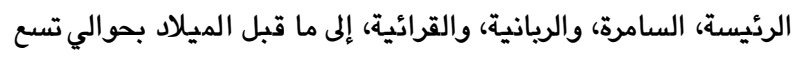

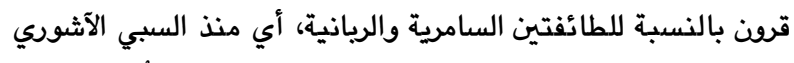

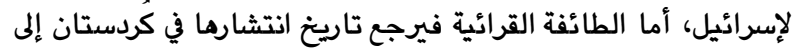

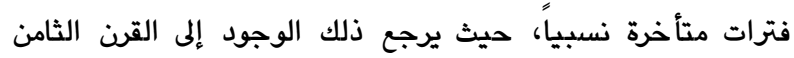

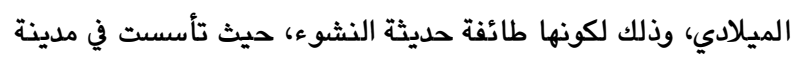
بغداد في القرن الثاني الهجري/ الثامن الميلادي.

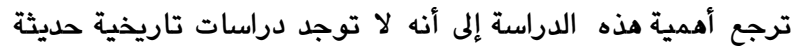
ومستقلة عن الأصول المذهبية ليهود كُردستان عامة، ويهود مدينة الهردية

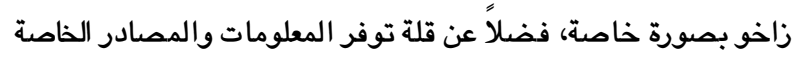
عن الموضوع، وكذلك لأن يهود كُرستان أنفسهم يبدو بأنهم كانوا متكتمين للإفصاح عن مذاهبهم، حيث كانوا فقط يظهرون يهوديتهم

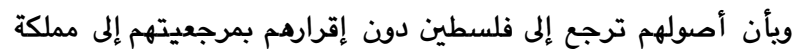

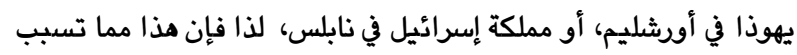
في معرفة حقيقة أصولهم المذهبية بدقة، ولوجود كثير من أوجه التشابه

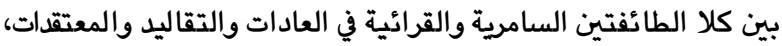


2. أن اسم السامري هو موسى بن ظفر (9)، ينسب إلى قرية تدعى

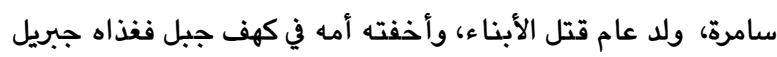

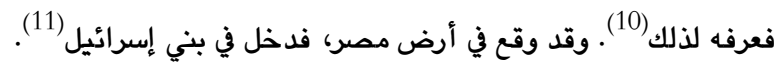

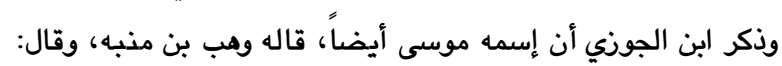
كان ابن عم موسى ابن عمران (12). 3. وي رواية ثالثة أن إسمه ميخا قاله ابن السائب(13).

2.2

1. قال قتادة: كان السامري عظيماً فيني إسرائيل من قبيلة يقال

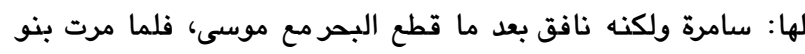

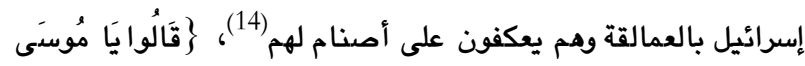

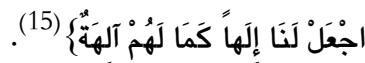
2. كان السامري من قوم يعبدون البقر، جيران لبني إسرائيل ولم يكن من بني إسرائيل (16). 3. نُقل عن ابن عباس (رض) إنس أن السامري كان من القبط، وكان جاراً لموسى آمن به وخرج معه ابن عباس (رض). 3.2 1. أن السامري ينسب إلى قرية تدعى سامرة(18.).وذكر القرطبي عن السامري بصيغة التضعيف وذلك بقوله: "قيل: كان عظيماً من عظماء بني إسرائيل، من قبيلة تعرف بالسامرة وهم معروفون بالشام" (19.

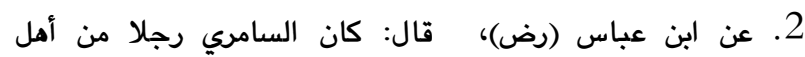
بَاجَرَمْا (20).

3. وفي رواية عن ابن عباس (رض) إنه كان من كرمان (21).

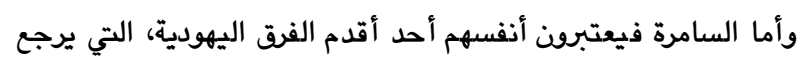

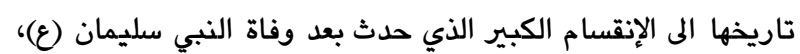

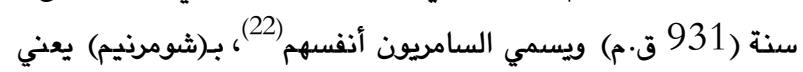
حراس الشريعة ويعتبرون انفسهم الاسرائيليين الحقيقيين، ويصلون

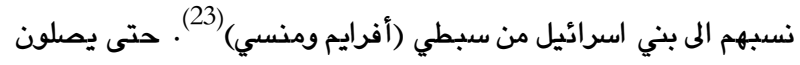
الى يوسف (ع) (24)، ويبدو أنهم اعتمدوا في ذلك على مائل ما ورد في العهد

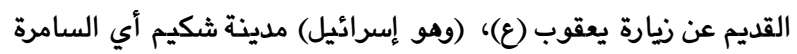

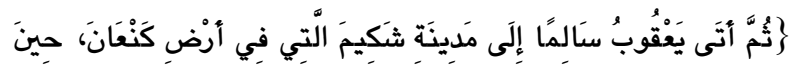

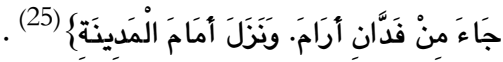

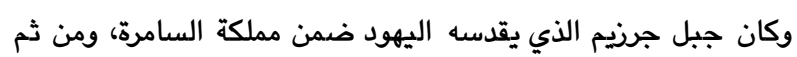

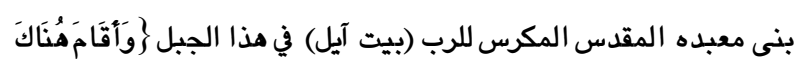

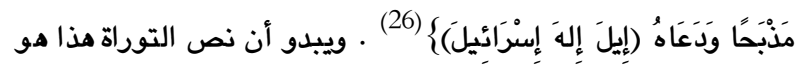

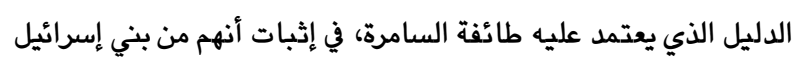
التي يشكك فيها أحمد سوسة بأهم بقية الباقية على الديانة اليهودية(27). وجاء هذا بشكل علني في تصريح رئيس طائفة السامرة بانهم من اليهود

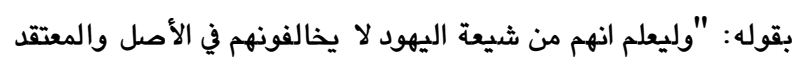

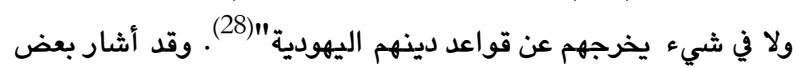

لوحظ وجود بعض التشابه بين معتقدات يهود مدينة زاخو مع طائفة

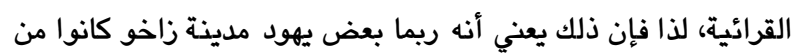
المتأثرين بمذهب الطائفة القرائية. لدراسة كل ما سبق بصورة علمية صديحة، فقد تم تقسيم البحث على بلى الطئ

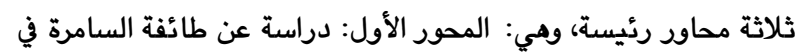

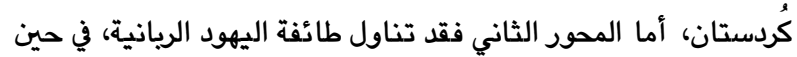
إمتم المحور الثالث من البحث بطائفة يهود القرائين.

\section{2.طائفة اليهود السامرة في كُردستان}

تعد فرقة السامرة من أوائل الفرق الدينية اليهودية والفكرية من الناحية

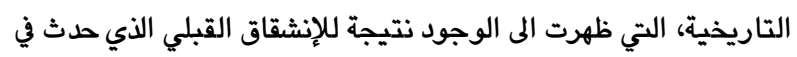

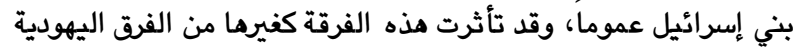
الأخرى بالأحداث والتقلبات السياسية خلال الدقب التاريخية المختلفة،

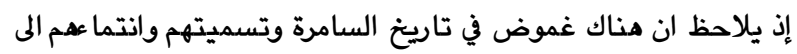
اليهودية، وذلك لتعدد وتضارب الآراء حولها، فمن حيث إنتمائهم المى

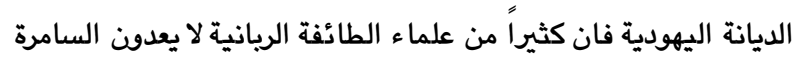

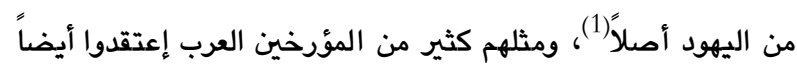

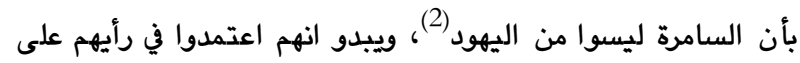

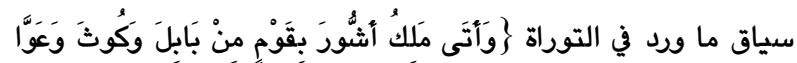

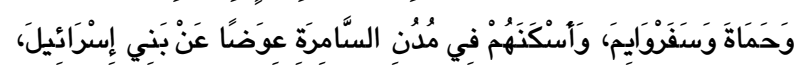

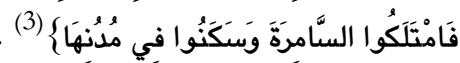
وهناك إثارة من المؤرخ المقريزي إلى أن طائفة السامرة ليست من يهود الئا

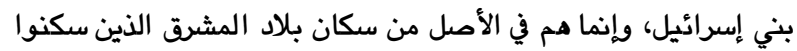

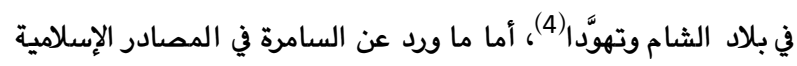

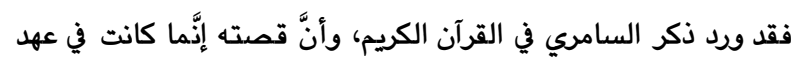
النبي موسى (ع)، وأخيه هارون، ومعلوم أن عهد موسى يعود إلى القرن

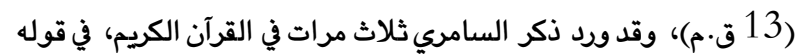

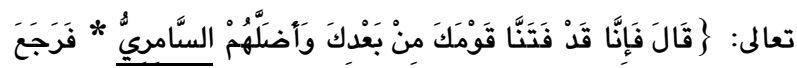

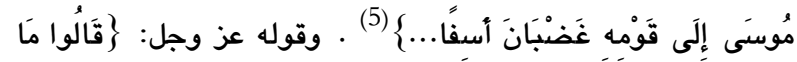

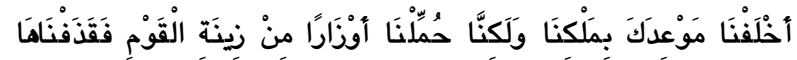

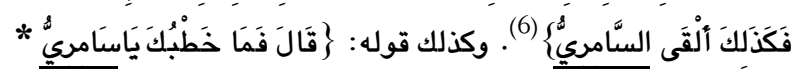

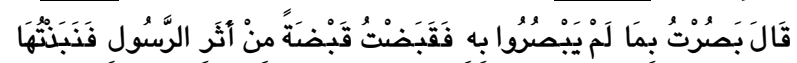

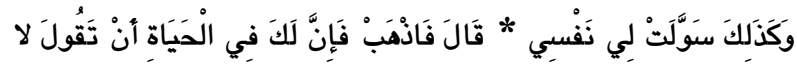

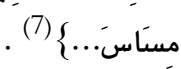
وقد إختلفت المصادر الإسلامية في بيان إسم السامري، وأصله،

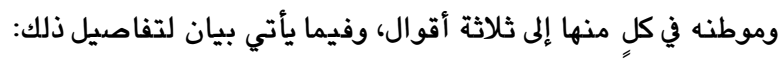

$$
1.2 \text { إسم السامري }
$$
1. لقد ذكر ابن كثير أنه ورد في الكتب الإسرائيلية أن إسمه كان 
العشرة(42)، من بنى إسرائيل وقبلتهم في جبل جرزيم، ويمرور الزمن أصبح إسم السامرة يطلق على المنطقة الشمالية في فلسطين الذي كان إنسران

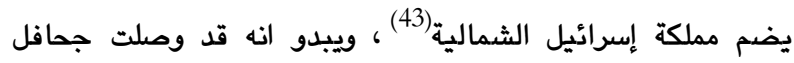

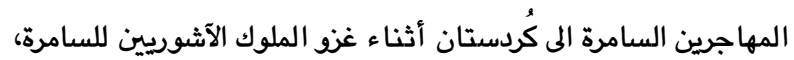

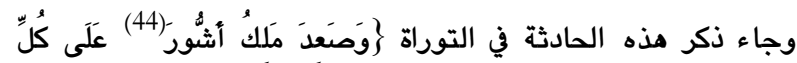

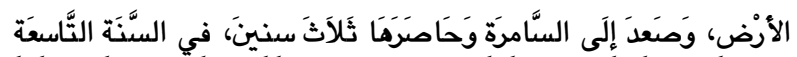

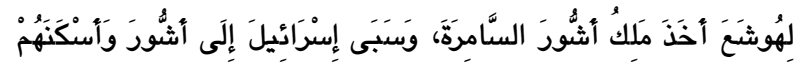

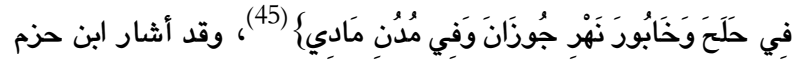
الاندلسي الى حادثة سقوط دولة السامرة وسبي الأسباط العشرة من مدي مادي بني إسرئيل على يد ملك الموصل (الآثوري) الى آمد ويلاد الجزيرة

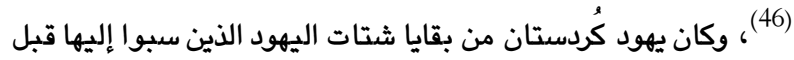

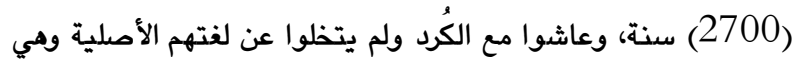
اللغة الآرامية تلك اللغة التي إستخدمت من قبل عيسى (ع)، وقد تمسَّك الثك بتلك اللغة يهود كُرستان ويعض المسيحيين الذين عاشوا معهم(47)، ويبدو ان يهود كُدستان حافظوا على عاداتهم وتقاليدهم وديانتهم الأصلية بما فيها لغة بني اسرائيل، فقد بقي يهود كُردستان يتكملون

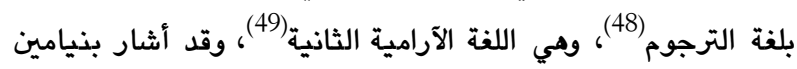
التطيلي الى وجود اليهود في المدن الكردية التي زارما بـ(كردستان الحالية) بإعتبارهم من بقايا اليهود الذين سباهم الملك الآثوري شلمنصر ويأنهم يتكلمون بلسان الترجوم، وكان من بينهم عدد كبير من علمائهم (50)، ويبدو أن يهود بلاد المادي كانوا متعلمين في العلوم

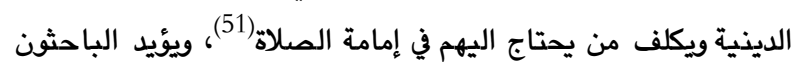
نقلاً عن يهود المنطقة الكردية أنفسهم بأنهم أحفاد اليهود الذين سباهم الآشوريون بقيادة تجلات بلاسر (732 ق.م)، وسرجون الثاني (722 (5) ق.م)، وسنحاريب (701 ق.م)(52) ، وكان لديهم توراة خاصة بهم وهي

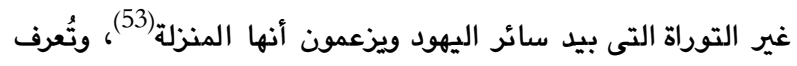
توراتهم هذه باسم ماسورات (masoretic)، وهي مدونة باللغة العبرية ولكن بأحرف عربية(54) ويبدو انه هناك تشابه كبير بين إسم ماتم الخط الذي استخدمه الكرد أثناء حكم الدولة الأموية والتي عثر في خزانة

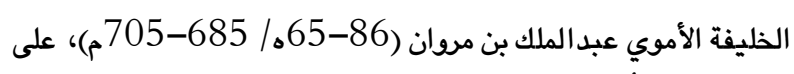
كتاب بخط الكرد بإسم ماسي السوراتي (55).وقد ورد في إنسكلوبيديا يهود كُردستان، وهي موسوعة مكتوية باللغة العبرية، بأن يهود مدينة

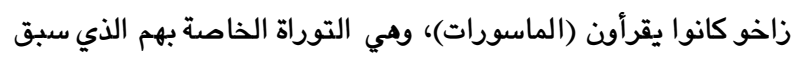
ذكره قبل قليل (56).

وهناك إثارة صريحة في كتب الرحالة على وجود قبر النبي ناحوم الألقوشي في بلدة ألقوش(57)، التي يوجد فيها قبره وقد ذكره الرحالة الرباني بنيامين التطيلي في رحلته، لأن المقابر كانت من أولويات

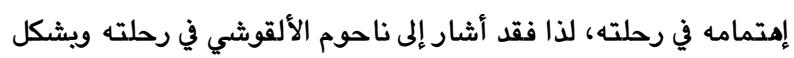

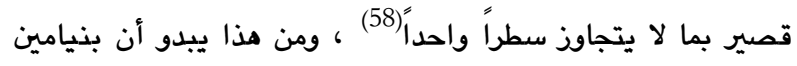
التطيلي قد قلَّل من أهمية قبر هذا النبي ريما لانه كان من سبايا بني
مؤرخي التاريخ الإسلامي المى يهودية السامرة وذلك على أساس بأن السامرة كان يحسب لهم حساب أهل الذمة لأنهم شعب منهم(29)،

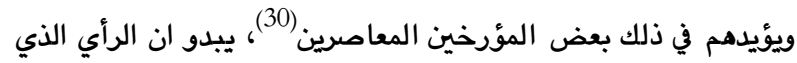

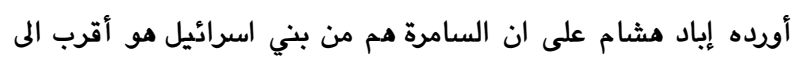
الصواب وذلك لإعتماده على ان عدد السبي السامري الذي ورد ذكره في التوراة وهو (27290)، لم يكن عدد سائر مملكة اسرائيل اي السامرة، وإنما كان فقط الكهنة والقادة وافراد من تبقى من الطبقة الحاكمة، وأنَّ طَلَبْ سُكان السامرة من الملك الآثورى على ان يبعث لهم كاهناً يعلمهم أحكام الدين، وهو خير دليل على أن هؤلاء السكان الباقين من السامرة من بني اسرائيل(31). بالرغم من إصرار التلموديين على أن السامرة لا ينتمون الى العرق اليهودي النقي، وذلك لإختلاطه بالعرق الآثوري، بعد السبي الآثوري

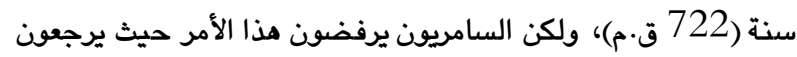
أصلهم الى بني إسرائيل ويتخذون من تاريخ إنقسام مملكة سليمان (931 ق.م) بين مملكة يهوذا الجنوبية في أورثليم التي يقودها رحبعام ومملكة يربعام، الذي يقود الأسباط العشرة والذين يعدون أصلهم من سبط أفرايم بن يوسف في المملكة الشمالية بإسم السامرة كبداية لتواجدمم هناك(32). وكان المسيحيين أي الرومان يحسبونهم ضمن احد الطوائف اليهويية

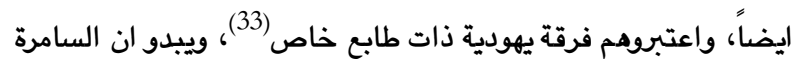
كانت مدينة قائمة حوالي سنة (880 ق.م) عندما إثترى ملك عُمري (885-874 ق.م) جبل من رجل اسمه شامر وينى فيه مدينة

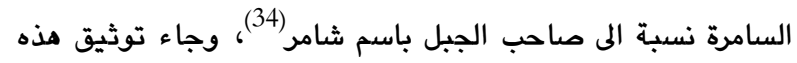

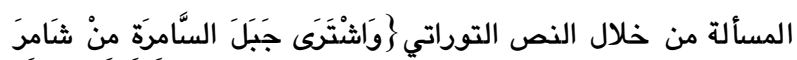

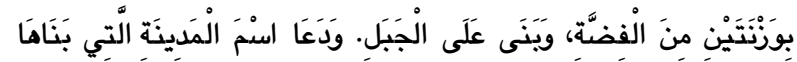

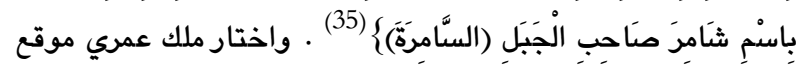
جبل السامرة وذلك لحصانته، ويقيت عاصمة لإسرائيل او الأسباط

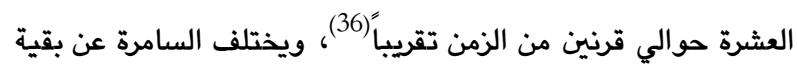
اليهود في إيمانهم بالتوراة فقط ويسمونها توراة موسى (أي الأسفار

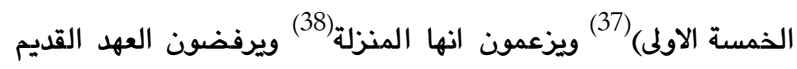
جملة عدا سفر يوشع، كما يرفضون التلمود ايضاً وتمثل التوراة نصاً سابقاً على نص ماسورا (39)، مع بعض الاختلافات ومنها نص وصايا العشر على ان مكان البيت الذي اختاره الرب وهو جبل جرزيم في

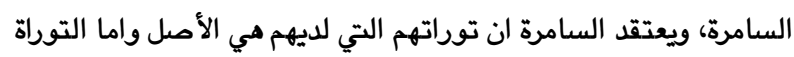
التي لدى طائفة الربانية وهي محرفة وقد كتبت على يد عزرا أحد كتبة الطائفة الريانية(40). السامرة وهي فرقة دينية إثتق إسمها من إسم مدينة كنعانية على

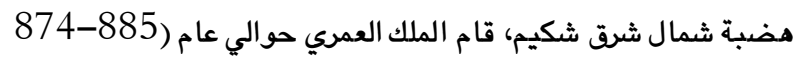
ق.م) بجعلها عاصمة لمملكة إسرائيل وإسمها العبري شوميرون ومعناها مكان المراقبة(41)، حيث إقترن إسم السامرة بإسم الأسباط 
والجدير بالذكر أن يهود زاخو كانوا يختلفون عن يهود السامرة في إستقبالهم لبيت المقدس، حيث كان اليهود السامرة على العكس منهم يستقبلون جبل نابلس في صلاتهم (70)، وريما سبب هذا الخلاف يعود

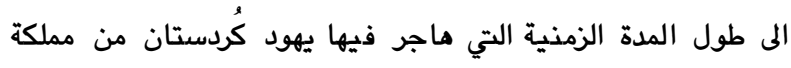

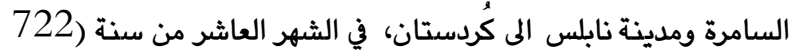
ق.م) على يد الملك الآثوري سرجون الثاني، وقد عثر العالم الأثري (بوتا) سنة (1843م) على مسلة سرجون الثاني التي كُتبت باللغة

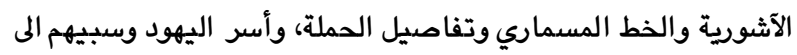

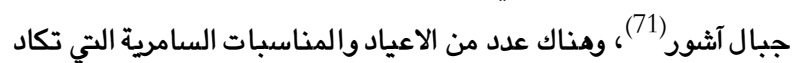
تكون قريبة من أعياد يهود مدينة زاخو ماعدا عيد الحانوكة، الذي يعد من الأعياد القومية والدينية في آن واحد لدى اليهود، حيث يشعلون الشموع في مواكب خاصة هذا اليوم، مكون من شمعدان خاص من تسع

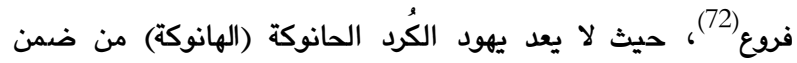
أعيادهم الرئيسية، وهو يظهر بجلاء من خلال عدم إمتناعهم عن العمل في هذا اليوم وعدم جعله عطلة إلزامية، وقد دخلت كلمة حانوكه في

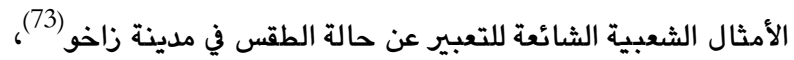
وأما عيد الأسابيع وهو ثاني أعياد الحج عند السامرة ومن أبرزطقوس على هذا العيد وهو الصعود على جبل جرزيم لتلاوة التوراة كلها، ومناسبتها الى ننول التوراة والوصايا العشر على النبي موس (ع) على جبل سيناء في مصر(74)، ويسمى هذا العيد اي عيد الاسابيع في زاخو بعيد

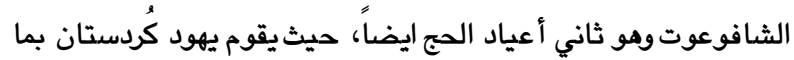
فيهم يهود زاخو بزيارة قبر ناحوم الألقوشي ويصعدون الجبل شمال القبر الذي يسمونه بـ(هاى سينای)، اي جبل سيناء لتلاوة الوصايا

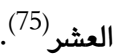
أما عيد الفسح أوعيد الفطير فهو من أعياد الحج الأولى، وهو اكبر اعياد السامرة الذي يبدأ من يوم الرابع عشر من شهر نيسان، ويستمر مدة

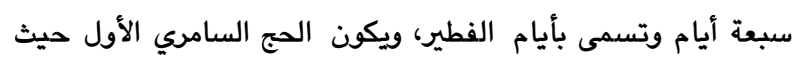

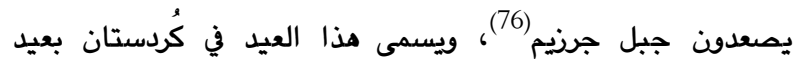
(الباسفور) بلغة الترجوم وهو عيد الفصح ويسمى بالعبرية (البيساج) ويعد من الأعياد الرئيسية عندهم، حيث يتوجه اليهود فيه من القرى بلهي الى المدن للإحتفال بهذا العيد مع الأقارب ويجلبون معهم قرابينهم وخبز من لهيت الفطير أي غير المتخمر، وكان يهود حميدية (عقرة) وقِدش وأرَدَنَ ويامرني وأنيشكى يتوجهون الى ضواحي العمادية لإقامة مراسيم هذا العيد، بحضور رجل الدين، ويسمى هذا العيد بعيد بهيرة (عيد الربيع)

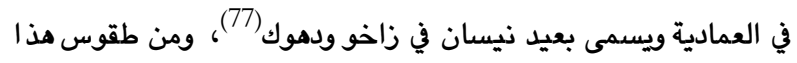

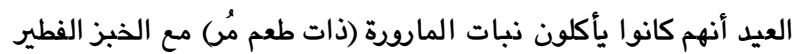
والذبيحة(78) وكان لهذا العيد تسمية قريبة من هذا الطقس حيث كانو نوات المارو يسمون هذا العيد باللغة الكُردية بعيد (تحليشكة) اي عيد أعشاب تحريه المرة(79).
اسرائيل في عهد شلمنصر الخامس الآشوري المعروفين بالأسباط العشرة (أي السامرة).

وينقل يوسف بابانا عن لايارد العالم الأثري ان نبوة ناحوم ظهرت في زمن الاسباط العشرة، وان كتاب سفره المعرف بسفر ناحوم الألقوثي

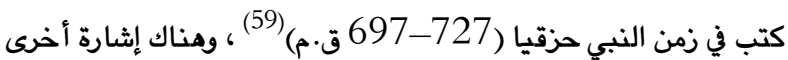
يظهر فيها إنتماء النبي ناحوم إلى طائفة يهود السامرة، وذلك بأنه اودع نبوته ممتلاً سخطاً وغضباً على آثور في ثلاثة فصول من سفره (60)، وليس من سبايا بابل كما يذكر صاحب قاموس كتاب المقدس بأن ناحوم من سبايا الأسر البابلي، ويبدو انه خلط بين السبي الآثوري

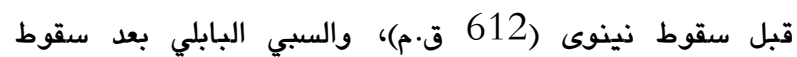
نينوى(61)، وكان هذا المزار يُزار من قبل حجاج اليهود في منطقة كردستان بعيد شافوعوت، وهي اكثر أعياد ومناسبات الحج احتفالية وهو الحج الى ضريح النبي ناحوم في ألقوش، والذي يشترك فيه الآلاف من اليهود من العراق وكردستان، حيث يصعدون مرتفع يسمونه (هار سيناي) كي يقرأوا على قمته الوصايا العشر (62). والجدير بالذكر أنه كان من جملة اعياد الحج في زاخو عيد كان يُعرف

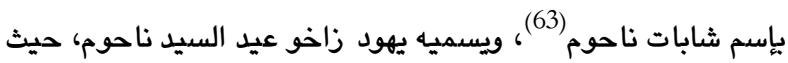
كان يهود مدينة زاخو يزورون ضريح النبي ناحوم الألقوثي بمناسبة

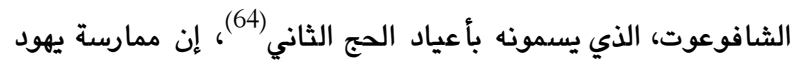
زاخو لطقوس هذا العيد وذلك بزيارة ضريح النبي ناحوم في ألقوش يدل بوضوح على أنهم كانوا من يهود الأسباط العشرة السامرة، ويبدو ان السامرة كانوا لا يهتمون بقراءة شروحات وتفاسير المشناة والجمار، التي تسمى بالتلمود وقد جرت العادة لدى يهود كُردستان في زاخو والعمادية ومدينة سنه، عدم إيلاء أي إهتمام لها أيضاً ويقول براور في هذا الصدد: "ثروح الأحبار بالآرامية على المشناة تؤلف التلمود نفسها إهاء غير معروفة في العمادية وزاخو، ودهوك، وسنه "(65).

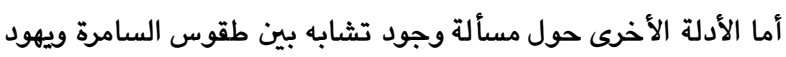

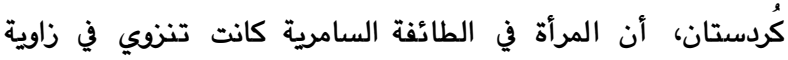
مخصصة لها في فترة الحيض ولا يجوزلها ان تخالط زوجها أو أهل بيتها لمدة سبعة أيام(66)، وكذلك الأمر بالنسبة للمرأة اليهودية بكردستان في فترة الحيض فإنه كان لا ينبغي لها أن تجلس على الطاولة التي يجلس عليها باقي أفراد الأسرة، وكان ينبغي أن تأكل لوحدما،

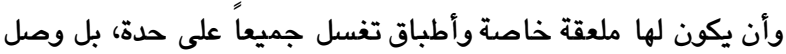

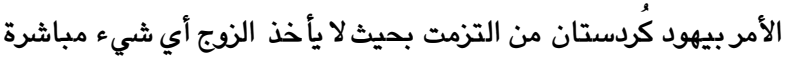
من يد نوجته خلال فترة الحيض، وينطبق هذا الأمر على الفتاة غير المتزوجة أيضاً حيث لا يأخذ الوالد شيئاً من يد إبنته مباشرة في فترة فئرة حيضها (67)، وكانوا يبالغون بمسألة الطهارة أكثر من سائر اليهود (68)، وكانوا لا يمسون الناس واذا مسوهم إغتسلوا (69).

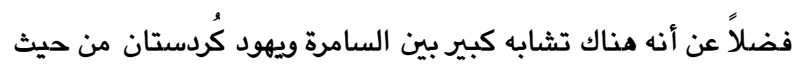
التزامهم بقدسية يوم السبت، والنظافة، والأعياد، وزيارة القبور، 
اليهودي بنيامين التطيلي الى حركة داود الروحي(90) في العمادية في القرن الثاني عشر للميلاد بقوله: "كان هذا قد تلقى العلم في بغداد عن حسداي رأس الجالوت، وعن علي رأس المثيبة (غاؤون بغداد)(91). فتظلع بالتوراة والفقه والتلمود...)( (92). نفهم من كلام بنيامين التطيلي داود الابن الروحي كان أحد طلاب رأس الجالوت حسداي وصمؤيل بن علي الملقب بابن الدستور، المتعمق بالشريعة المكتوية والشفوية وكان أغلب تلاميذه يأتون اليه بعد أن درسوا في مدنهم وقراهم ويحضرون أمام رأس الأكادمية(93)، رأس باتس المثيبة (غاؤونية بغداد)، الذين يعدون من الدور الرابع من أدوار علماء الريانية الذين تعاونوا في وضع التلمود(94). أما الإثـارة الثانية في النص فهو الـ(تظلع بالتوراة والفقه والتلمود)، وكانت الريانية تعترف بالتلمود الشفوي الذي وضعه علماء اليهود وفقهائهم ونسبوه الى الله عن طريق النبي موس (ع)(95) وهناك إثارة أخرى وردت في كتاب السمؤال بن يحيى المغربي، يظهر منها بأن داود ابن الروحي المسمى لديه بمناحيم سليمان "قد تفقه في دينهم بالاضافة الى جمهور من اليهود الساكنين بالناحية المعروفة بـانية بالعمادية من بلاد الموصل"(96) ، ويبدوبأن فرقة الربانية كانت أكثر لإضثر نشاطاً في إنشاء كيان لليهود والعودة الى أورشليم وهم يعتقدون بأن دولة اليهود لابد ان تستعيد مكانتها(97)، وكانت هيلانة وإبنها إيزاط الثالث أمير إمارة حدياب(98)، ويبدو انه كان هناك علاقة بين يهود إمارة حدياب في أربيل واليهود الفريسية الريانية في مملكة القدس (99)، وهذا ما يدفعنا إلى القولبأن العائلة المالكة في حدياب كانت تنتمي إلى طائفة اليهود الريانية، وهناك إثارة أخرى إلى تواجد الربانيين في كردستان،

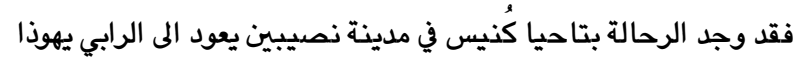
بن بثيرة(100)، وهو أحد كبار علماء التلمود في القرن الأول الميلادي

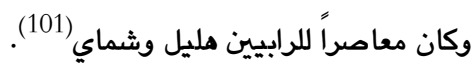

\section{4. القرائية في كردستان}

وهي احد اهم الفرق اليهودية التي تعود تاريخ ظهورها الى القرن الثامن الميلادي، والتي كانت احد اهم اسباب ظهورها انتشار الاسلام في الشرق وطرحه لمفاهيم جديدة حيث أصبح تحدياً حقيقياً للفكر الديني اليهودي(102). وأما عن تاريخ ظهور هذه الفرقة فالذي ورد في بعض اهري المصادر الإسلامية، أن عنان بن داود قد ظهر ببغداد في أيام الخليفة العباسيى ابو جعفر المنصور (136-158هـ/754-775م) (103) . حيث انهم لا يتعدون شرائع التوراة وما جاء في كتب الانبياء، ويتبرأون

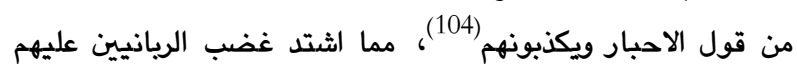
فضلاً عن تكفيرهم وعدم الزواج منهم، مما حدابهم إلى أن يشكوا أمرهم إلى الخليفة ابو جعفر المنصوربأتهام عنان بن داود بالزندقة ونقض

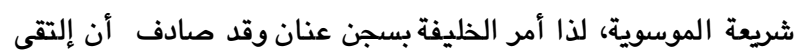
عنان بالإمام ابو حنيفة النعمان في السجن، فنصحه الإمام بان يشرح
من هذا يظهر بوضوح أن يهود مدينة زاخو كانوا ينتمون إلى الطائفة السامرية، وذلك لتشابه طقوس عباداتهم مع الطقوس الدينية التي كان يمارسها طائفة يهود السامرة، وقد تم تأشير عدة حالات تشابه بينهما، منها زيارة يهود مدينة زاخو لقبر ناحوم الألقوشي وذلك بإعتباره أحد أنبياء طائفة السامرة، وموقف يهود مدينة زاخو المتزمت من المرأة في فترة الحيض، وهو من أبرز الممارسات الدينية لدى السامرة، والمبالغة بمسألة الطهارة اكثر من غيرهم من الطوائف الأخرى، حتى وصل الطر بهم الأمر إلى عدم مس الناس وإذا مسوهم إغتسلوا، فضلاً عن أنه يوجد مند هناك تشابه كبير بين السامرة ويهود كُردستان من حيث التزامهم بقدسية يوم السبت، والنظافة، والأعياد، وزيارة القبور، وغيرما من الأمور التي تدل على صحة ما ذهبنا إليه عن الإنتماء المذهبي ليهود مدينة زاخو.

\section{3. الربانية في كردستان}

تعد فرقة الريانية(80)، إحدى أكبر الفرق اليهودية وأوسعها إنتشاراً

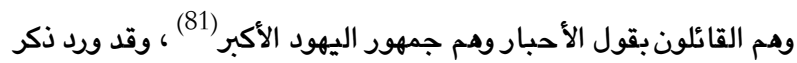

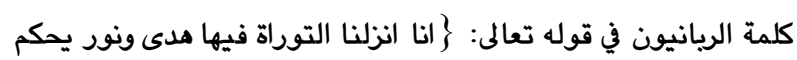
بها النبيون الذين اسلموا للذين مادوا والربانيون والاحبار بما استحفظوا

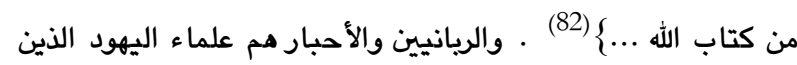
يزودونهم بالعلم ويريون صغارهم قبل كبارهم (83) ، وأما عن تاريخ هذه علماء اليهود لإنين الفرقة فتعود ظهورها الى ما قبل الميلاد بقرنين من الزمن وكانوا يعرفون بإسم الفريسيين الذين أوجدوا الشريعة الشفهية، الذين يتبعون عزرا الكاتب المتوفي (444 ق.م) وكان للفريسيين تواجد كبيى في بداية ثورة

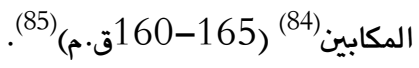

وكان قادة وحكام المكابين في فلسطين من الطبقة الفريسية، وكان مركانوس نفسه أحد ملوك الدولة المكابية من الطبقة الفريسية المعتزلة

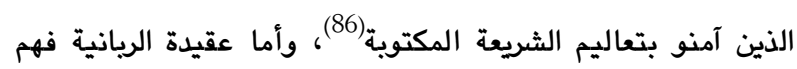
يؤمنون بالتوراة أي عهد القديم بأسفاره التسعة والثلاثون ويالتلمود الشفهي (87)، وتعول في احكام الشريعة على ما ورد في التلمود التي هي مجموعة من آراء الأحبار(88)، وأما عن وجود طائفة الريانية في بلاد الكُرد يبدو أنه كان هناك تواجد لليهود في بلاد الكُرد تعود الى عصود

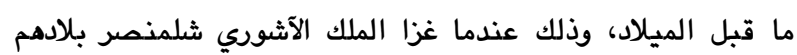
واستوطنهم في بلاد الكُد التي ذكرت في التوراة بإسم مدن مادي( ويقصد بمدن المادي بلاد الكُرد، وقد كان من الطبيعي وجود الفرق بلاد

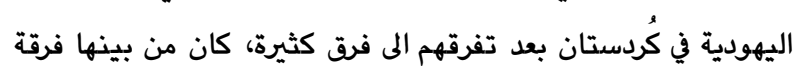

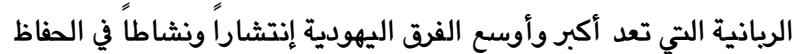

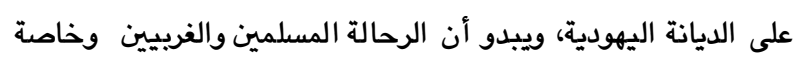

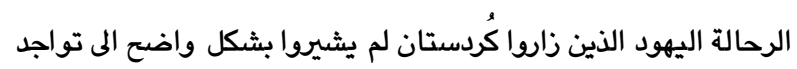
فرقة الربانية فيها، ولكن نستطيع إستنباط بعض النقاط من بطون كتاباتهم عن تواجد هذه الفرقة في كُرستان منها أثناء إثارة الرحالة 
الدعوة عنان بن داود كان يشدد في أحكام يوم السبت، حيث حرم إجراء الختان وحرم الخرجج من البيت في بلد يسكن فيها اليهود مع بـ الغرباء (المسلمين مثلا)؛ وحتى منع إشعال الشموع في السبت وقد حدد لهد القراؤون الخرج(120)، وفقاً التوراة(121)، يبدو ان طائفة يهود كُردستان فئان

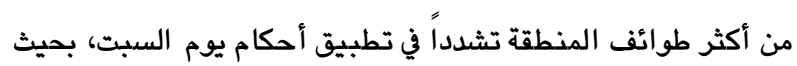

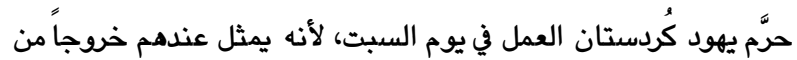
الدين حسب إعتقادهم (122).

ويذكر العالم براور حوادث تاريخية يظهر منها إنتماء يهود منطقة

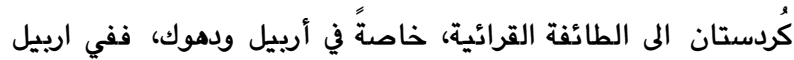
عوقب احد الآباء لأن ابنه أشعل عود ثقاب يوم السبت بغرامة مالية، وذُكرت حادثة تاريخية أخرى قبل حوالي 150 عام عن الحبر ناثانيل هاليفي وابنه شمؤيل البارزاني، ويلخص القصة بأن الإثنين قد خالفا القوانين لذا حضروا بين يدي احد شيوخ المنطقة بعد ان انتهى من الحوار، ولكن محاكمتهم قد تأجلت وطلب الهاليفي من إبنه بأن يرجع الى البيت ويقضي يوم السبت في البيت، وعندما طلب الإبن الخروج من بارزان والهرب إعترض الحبر اليهودي ناثانيل الهاليفي على ذلك لكي لا يخالف أحكام السبت (123). ومن المعلوم ان عنان بن داود صاحب العنانية، كان يرى بأن وصايا الرَّب هي فقط التي منحت للنبي موسى (ع) على جبل سيناء، وكان

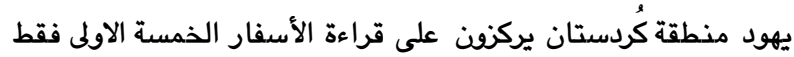
من التوراة، التي تسمى بأسفار موسى حيث وجدت المخطوطة بأسفارها الخمسة في دياريكر وماردين(124) ، وكان ظهور الصهيونية وفكرة إنشاء الوطن القومي لليهود يخطط له وتعد العدة له من طائفة يهود الريانية، ولم يكن في تفكيرهم الواعي ولا في عقلهم الباطن اي حساب للقرائين، وهكذا كانت الفرقة القرائية معادية للصهيونية منذي ولن البداية(125)، ويشير الرابي بتاحيا بشكل علني بعدم إنتماء القرائين الى

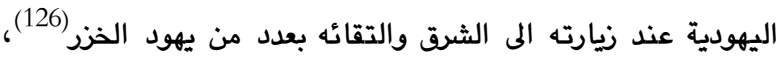

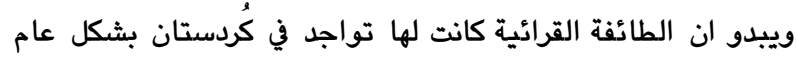

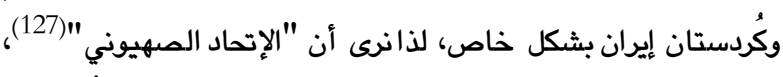
طالب قادة الصركة الصهيونية في إيران بعدم السماح ليهود كُردستان التابعة لإيران بالهجرة الى اسرائيل(128)، وهناك إثـارة من الرحالة

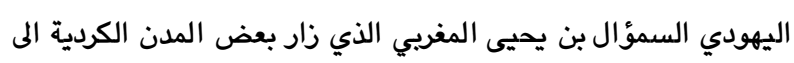

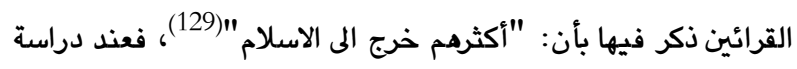

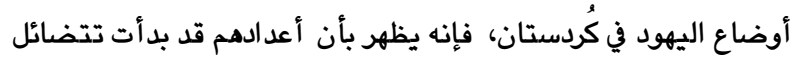
بمرور الزمن، ريما بسبب تغيَّرهم لدينهم وذلك عن طريق دخولهم في

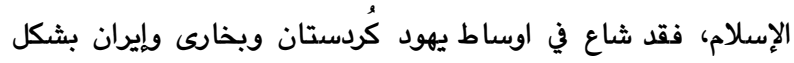
ملحوظ، حيث شهدت المدة الممتدة في القرن السادس العشر الى السابع عشر الميلادي، إعتناق عدد كبير من يهود إيران وكُردستان للإسلام لأسباب مختلفة(130).
للخليفة بأنه أراد تطهير اليهودية من شوائب التلمود، التي وضعها أحبار اليهود، ويبدو انه استطاع أن يقنع الخليفة بذلك لذا أمر الخليفة

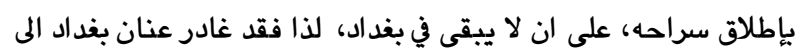
القدس حيث بنى كنيساً لجماعته هناك (105).

وأما عن تسمية الفرقة فيبدو انه هناك اختلاف في تسمية هذه الفرقة في المصادر الاسلامية، حيث ورد في بعض المصادر التاريخ الاسلامي

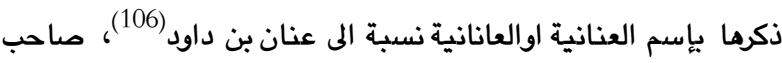

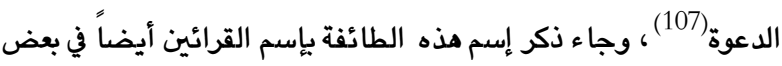
المصادر الاسلامية الأخرى (108). من المعلوم ان هذه الحركة هي حديثة العهد بالمقارنة مع زمن تواجد

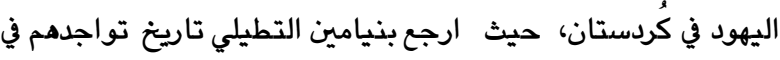

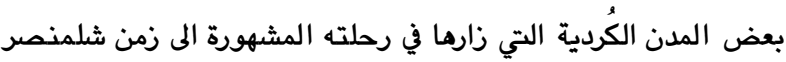

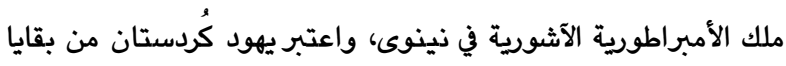
الجالية اليهودية الأولى أي الأسباط العشرة الذين سباهم الآثوريون (109)، وقد ذُكر اسم كُردستان في التوراة بإسم ماد

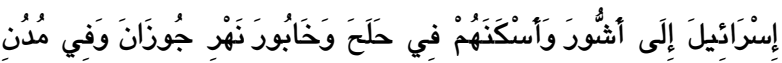

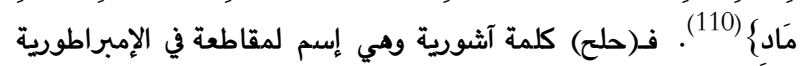
الآثورية قرب تل حلف في حوض نهر خابور شمال سورية "أي

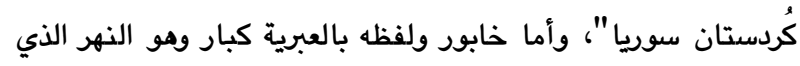
أُطلق عليه اليونان اسم "خابوراس" وسُُمي في التوراة باسم نهر جوذان وذلك لتمييزه عن نهر خابور الذي يصب في نهر الدجلة(111).

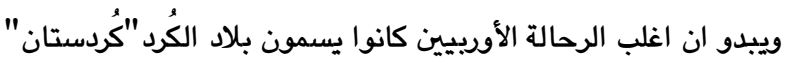
بإسم ماد، وهناك إثارة من الرحالة بنيامين فيها ذكر لبلاد الكرد بإسم الرمان

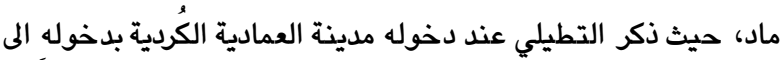
بلاد تخوم الماد (112). وهناك إثارة وردت في كتب التاريخ الإسلامي عن تواجد هذه الفرقة في العراق(113) ويبدو ان القصد من العراق عندهم هو المناطق التي تقع فئ شرق بغداد والتي تسمى بعراق العجم (أقليم الجبال) وهي تشمل بلاد الكُرد (كردستان) (114) ، وقد أطلقت عليها مصادر التران التاريخ الاسلامي إسم العراق، وقد جعل ابن حوقل أقليم الجبال (كردستان) ضمن حدود العراق أيضاً(115)، والتي تعرف بعل بعراق العجم في كتب الرحالة والجغرافيين العرب، وهي معروفة بإقليم الجبال والتي هي بحسب رسمهم لحدودها أنها تتوسط همدان وسط عراق العجم (116). يبدو ان عناصر من مذه الفرقة قد بقت الى فترات متأخرة تعيش في

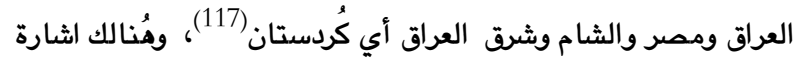
يظهر منها أن عنان بن داود صاحب الدعوة كان يتواجد في شرق بغداد، والتي هي بلاد الكرد (كردستان) ويلاد مابين النهرين قبل إعلان دعوته في بغداد(118)، وقد أثار أحد الباحثين الى تواجد فرقة القرائين في

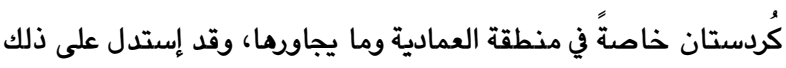

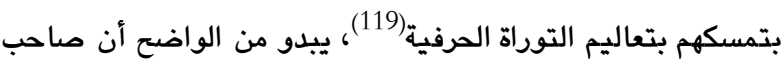


1. أن تاريخ الوجود اليهودي في كردستان قديم بصورة عامة، يعود إلى ما قبل الميلاد بحوالي تسع قرون بالنسبة للطائفتين السامرية والريانية، أي منذ السبي الآثوري لإسرائيل، أما الطائفة القرائية فيرجع

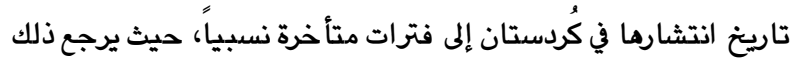
الوجود إلى القرن الثامن الميلادي، وذلك لكونها طائفة حديثة النشوء؛ حيث تأسست في مدينة بغداد في القرن الثاني الهجري/ الثامن الميلادي. 2. لوحظ وجود تشابه كبير بين يهود مدينة زاخوواليهود السامرة،

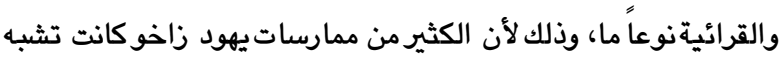
الطقوس التي تمارسها طائفة السامرة، ويعض طقوس طائفة القرائية التي كانت مشتركة بدورها مع طقوس السامرة، لذا يمكن القول بناء؛ على هذا بأن يهود مدينة زاخو كانوا على مذهب السامرة على الأغلب.

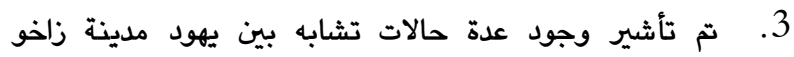
والسامرة، منها موقف يهود مدينة زاخو المتزمت من المرأة في فترة

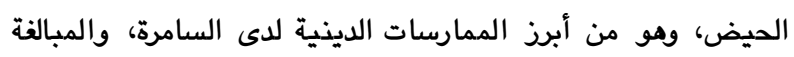
بمسألة الطهارة اكثر من غيرهم من الطوائف الأخرى، حتى وصل بهر الطم الأمر إلى عدم مس الناس وإذا مسوهم إغتسلوا، فضلاً عن أنه يوجد مند هناك تشابه كبير بين السامرة ويهود كُردستان من حيث التزامهم بقدسية يوم السبت، والنظافة، والأعياد، وزيارة القبور، وغيرما من لهن الأمور التي تدل على صحة ما ذهبنا إليه عن الإنتماء المذهبي ليهود مدينة زاخو. 4. يرجع تاريخ وجود اليهود في كُردستان الى قرون ما قبل الميلاد، وذلك عندما غزا الملك الآثوري شلمنصر بلادهم واستوطنهم في

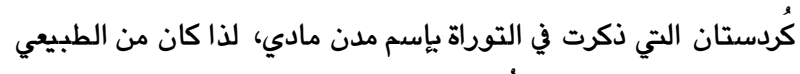

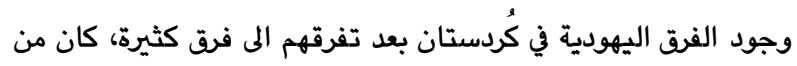
بينها فرقة الربانية التي تعد أكبر وأوسع الفرق اليهودية إنتشاراً ونشاطاً في الحفاظ على الديانة اليهودية.

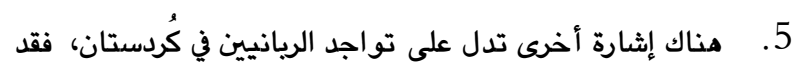

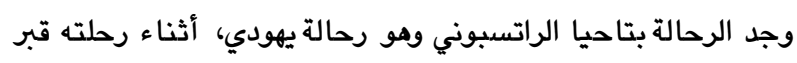
في كُنيس بمدينة نصيبين يعود الم الرابي يهوذا بن بثيرة، وهو أحد وهد رهاء كبار علماء التلمود في القرن الأول الميلادي وكان معاصراً للرابيين مليل وشماي، مذا فضلاً عن وجود مناحيم داود الروحي في مدينة العمادية،

وكان أحد تلاميذ غاؤونية بغداد التي تنتمي إلى مدرسة الريانية.

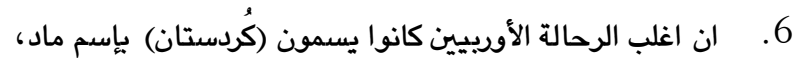
وهناك إثارة من الرحالة بنيامين التطيلي ذكر فيها مناطق سكن الكرد الردان التي عُرفت فيما بعد بـ(كردستان) بإسم (ماد)، فضلاً عن ورود إثارة في كُتب التاريخ الإسلامي عن تواجد هذه الفرقة في العراق، ويبدو ان القصد من العراق عندهم هو المناطق التي تقع شرق بغداد والتي تسمى

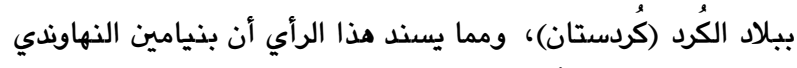

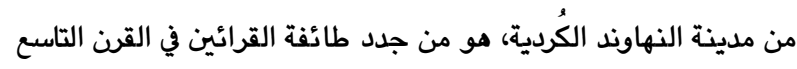
الميلادي، وغيَّر إسمها من العنانية وهو الإسم القديم لها إلى القرائية.
وأن وجود العالم القرائي المعروف بنيامين النهاوندي(131)، الذي يعد مجدد القرائية في نهاوند أحد المدن الكُردية، إثارةً الى وجود حركة لمرئ

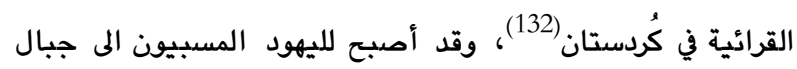

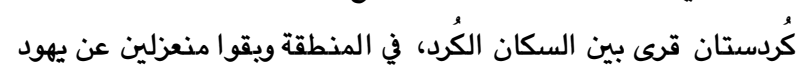

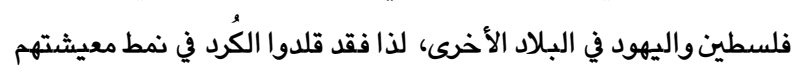
مع الحفاظ على لغتهم الآرامية عند سبيهم، وهي نفس اللهجة التي كان

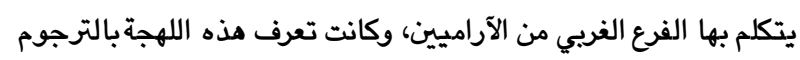
التي كانت تستعمل في فلسطين(133). ويبدو أن سكن طائفة اليهود القرائية هذه في جبال كُرستان قد فلد تسبب بعزلهم عن باقي اليهود في العالم، لذا أصبح من الصعب وصول الرحالة

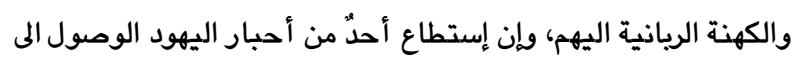
كردستان، فإنه كان يعرب عن تعجبه من (التوراة)، التي كان يعتمدها أحبار اليهود في كُرستان، والسنن التي كانوا يحدثونها ويلحقونها بالفرائض (134).

وهذا يدل بشكل واضح على أن يهود مدينة زاخو كانوا بعيدين عن

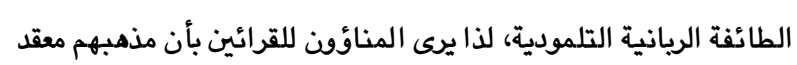
وهو مزيج من اليهودية والمسيحية والاسلام، كإعتقادهم في تحديد مواسم ومواقيت الاعياد والمناسبات وإقامة النافورات المائية في باحة ولها الكنيست للوضوء (135)، ويمكن إعتباربناء الكنيست الكردي قريباً من والن

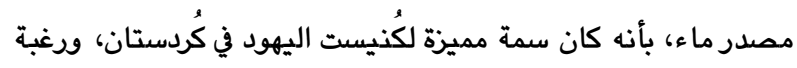
في الإغتسال الشرعي داخل الكنيست، حيث بنيت اغلب كُنيستات كردستان بقرب من الانهار فكنيست زاخو ودهوك وييت ناعورا جميعا بنيت قرب ضفاف الانهار، وقد تُمود الينابيع الى داخل الكنيسات في اماكن اخرى من كُردستان، كما في نيروه وجالا وبيجارواشنوية، على في الاني

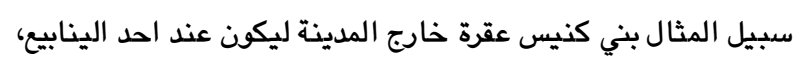
ويتدفق ماء الينابيع في قناة يتدفق احدهما الى باحة الكنيس و والاخرى تجتاز فناء الكنيس(136). ويبدو أنه كان يوجد تشابه بين طائفتي السامرة والقرائين، من حيث إعتمادهم على الأسفار الخمسة بالإعتراف بها دون التلمود، وكذلك بلك

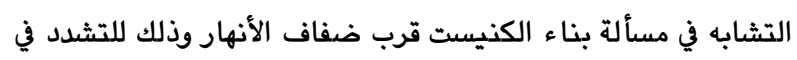
مسألة النظافة والطهارة، لذا فإنه من الصعوية الجزم بكون يهود مدينة زاخو كانوا من طائفة السامرة أو القرائين حصراً، وذلك لوجود كثير من إنهان أوجه التشابه بين كلا الطائفتين، إلا انه يمكن الجزم بأن يهود مدينة زاخولم يكونوا من طائفة الريانيين، وذلك لأن معظم الرحالة الذين زاروا

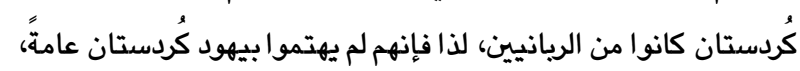
ويهود مدينة زاخو بصورة خاصة وذلك ريما لإنتمائهم لطائفة السامرة، أو القرائين.

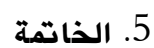
تتخلص نتائج هذه الدراسة فيما يأتي: 
33. . مراد فرج، القراؤون والربانيون، ص56" قاسم عبدة، اليهود في مصر،

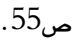

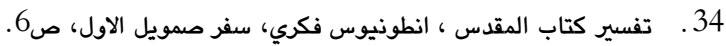

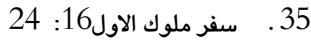

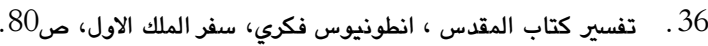

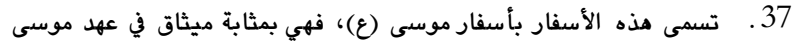

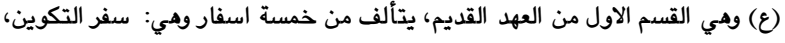

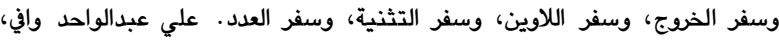

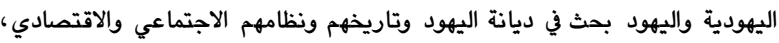
ص9. (20)

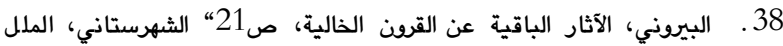

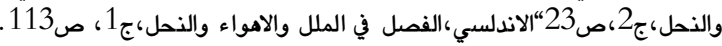

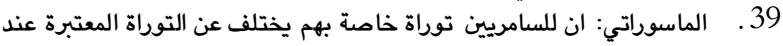

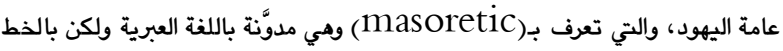

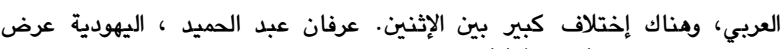

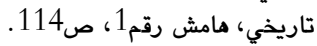

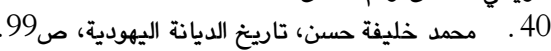

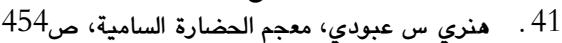

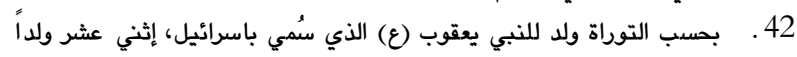

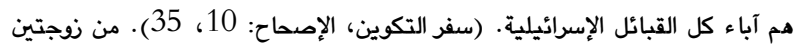

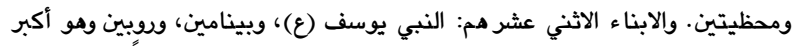

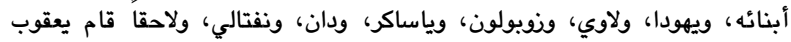

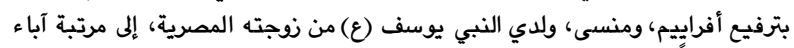

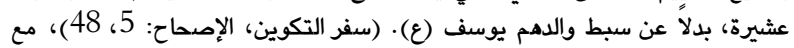

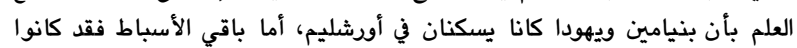

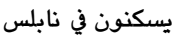

43 . اباد هشام محمود الصاحب، السامريون، ص21.

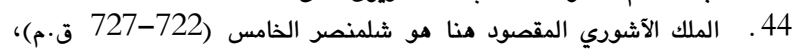

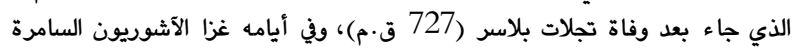

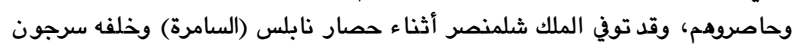

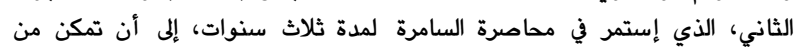

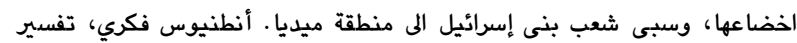

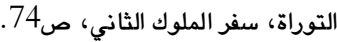

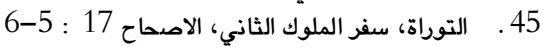

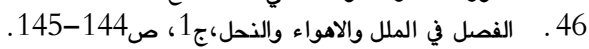
,my father paradise p3, Printed in the .47 ariel sabar U.S.A. New York ; 2008

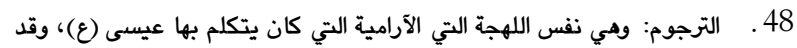

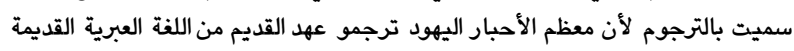

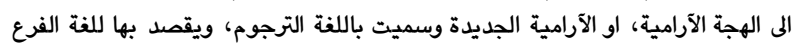

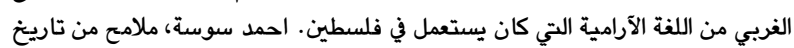

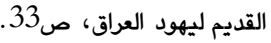

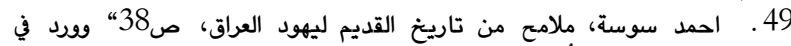

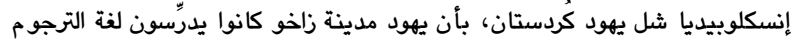

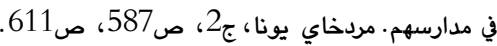

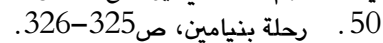

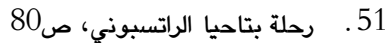

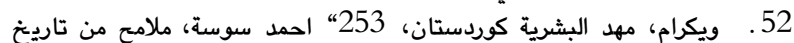

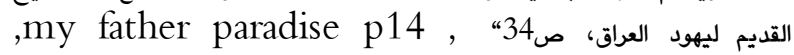
ariel Printed in the U.S.A. New York ; 2008

sabar

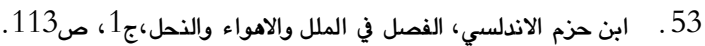

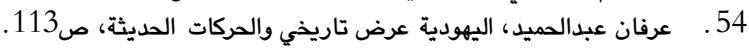

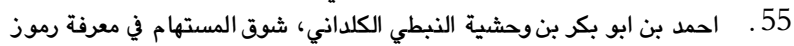

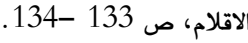

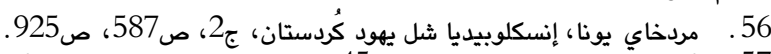

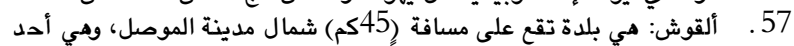

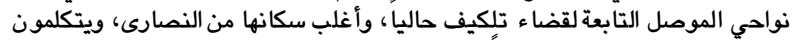

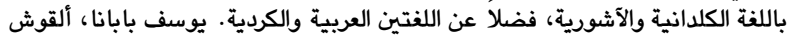

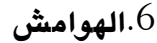

1. يوجد في نابلس حوالي الف من السامرة وليس فيها يهودي واحد. بينامين التطيلي، رحلته،244.

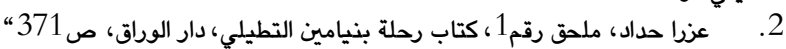

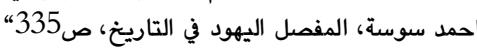

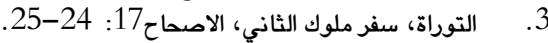

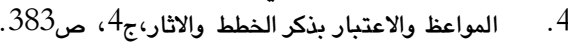
5.

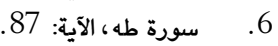
7. 8. 9.

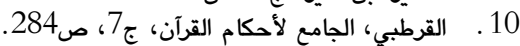

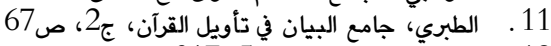

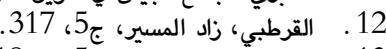

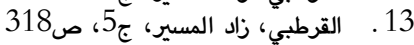

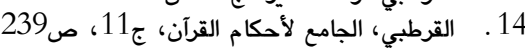

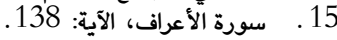

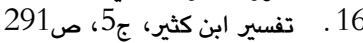

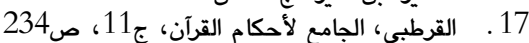

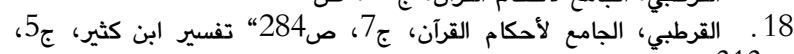

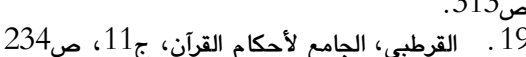

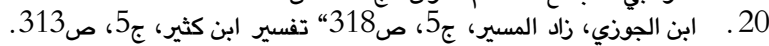

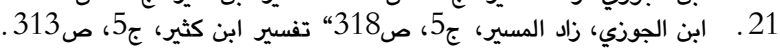

22. وأما عن تسمية السامرة فقد اطلقوا على انفسهم تسميات مختلفة منها:

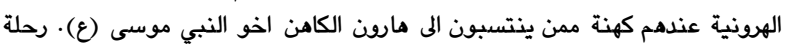

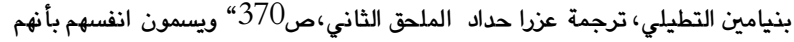

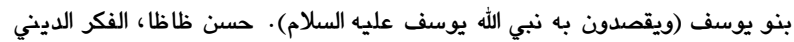

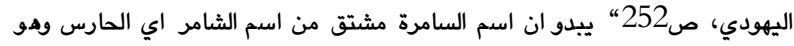

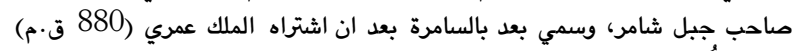

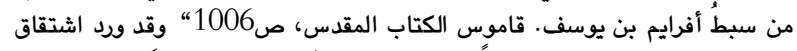

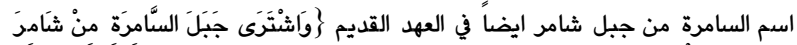

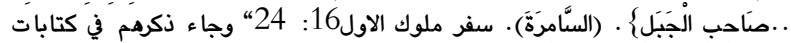

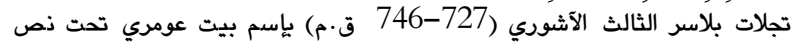

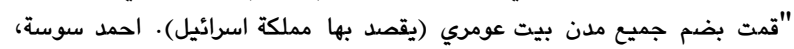

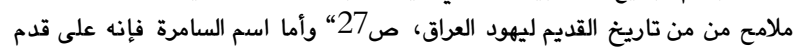

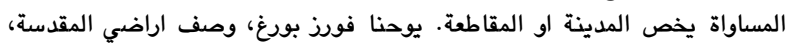

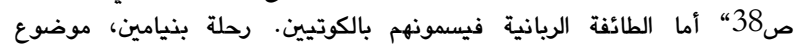

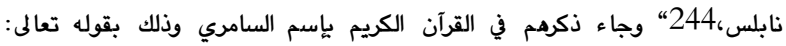

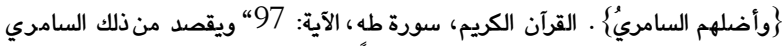

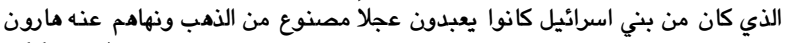

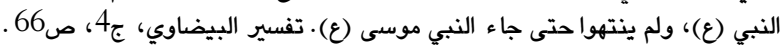

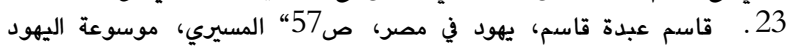

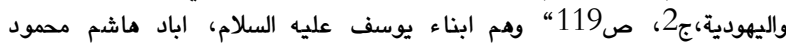

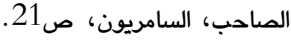

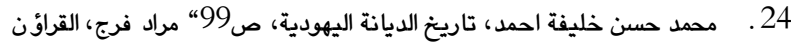

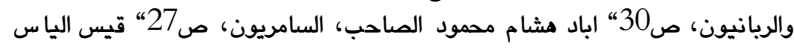

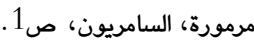

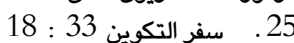

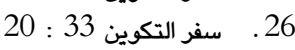

27. 28.

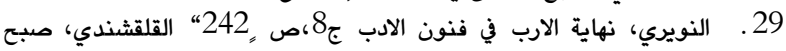

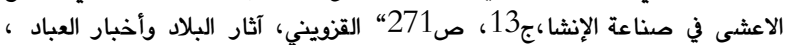

$$
\text { 30. قيس الياس مرموة، السامريون، ص27. }
$$

31. السامريون، صالياس صرمة.

32. محمد حسن خليفة الحمد، تاريخ الديانة اليهودية، ص219. 
وأوجب على جميع مواطني فلسطين أكل لحم الخنزير.ويموجٍٍ الأوامر الجبديدة انقسم

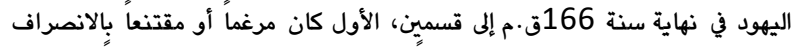

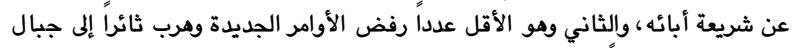

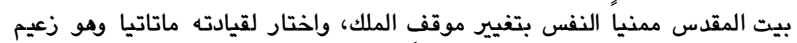

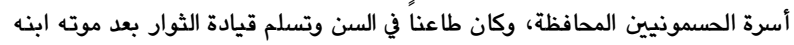

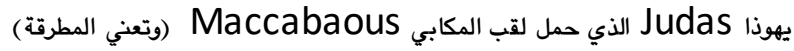
بعد اكتسابه ولاء معظم اليهود المتعصبين خارج بيت المقدس. ينظر لمكئ للمزيد: (العابد،

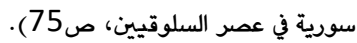

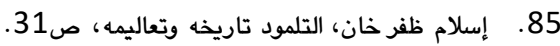

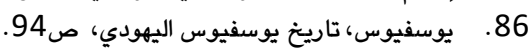

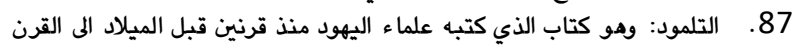

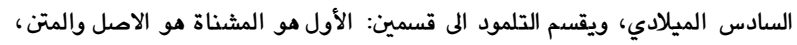

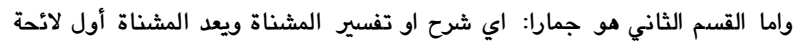

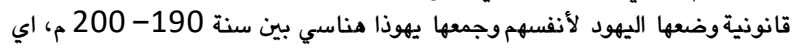

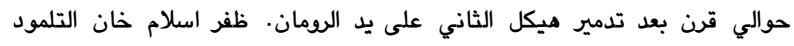

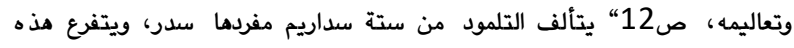

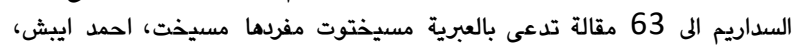

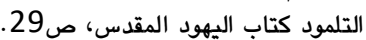

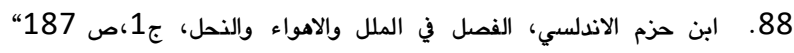

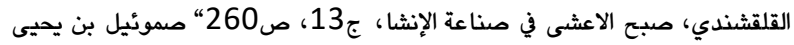

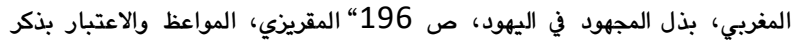

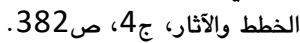

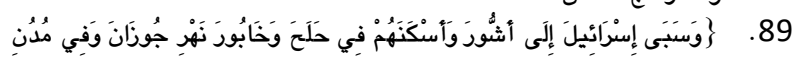

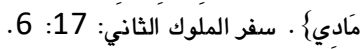

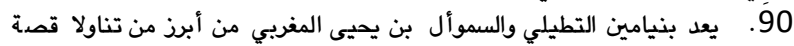

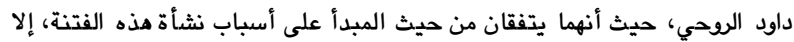

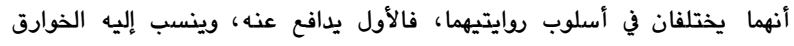

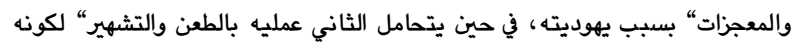

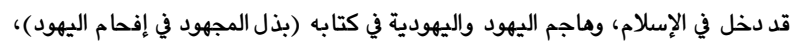

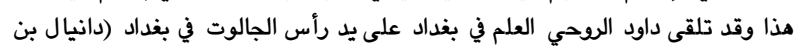

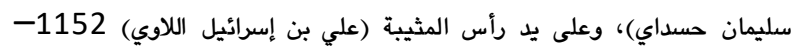

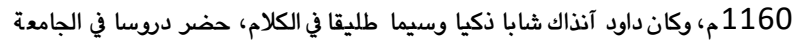

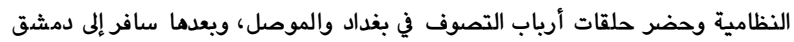

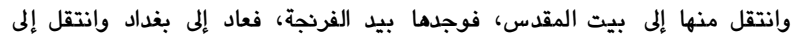

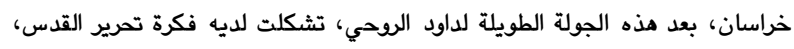

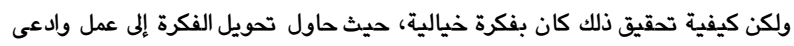

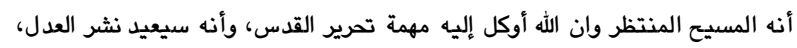

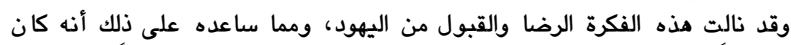

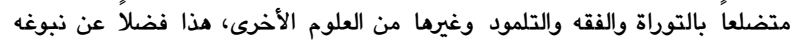

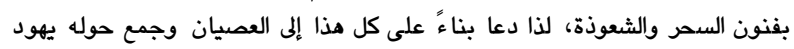

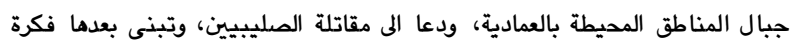

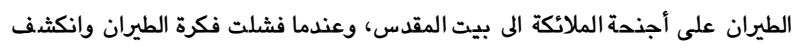

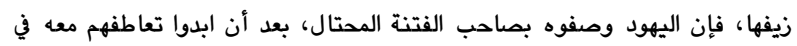

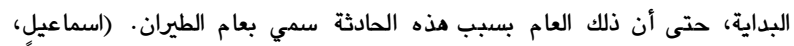
أدعياء المسيحانية في العصر الاسلامي - حركة داود الروحي العمادي لمادي نموذجاً، ص129-121-131).

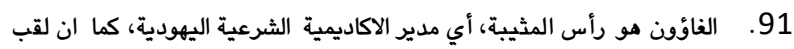

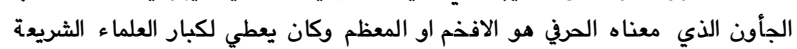

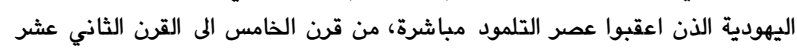

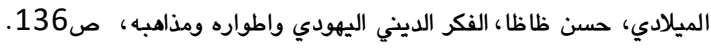

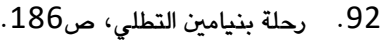

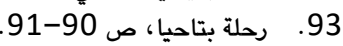

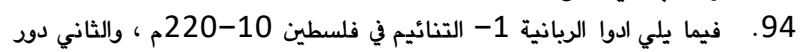

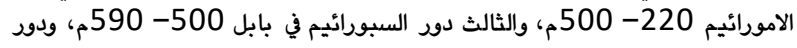
الرابع الغاؤونيم في بابل 590- 170 1030م، احمد سوسة، ملئ ملامح من تاريخ القديم

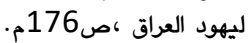

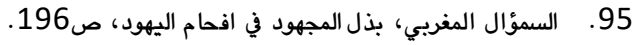

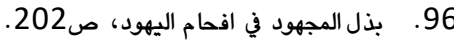

عبر التاريخ، ص28"، وهي الآن تقع ضمن مناطق المادة (140) حسب الدستور

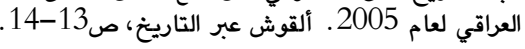

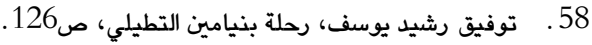

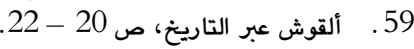

60 . يوسف غنيمة، نزهة المشتاق في تاريخ يهود العراق، ص213.

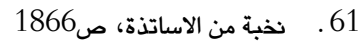

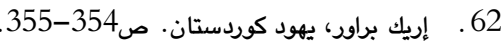

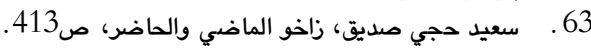

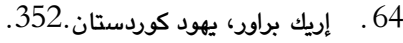
65. . إريك براور، يهود كوردستان. صوردستان.

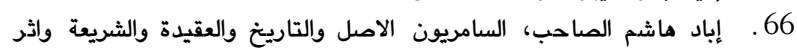

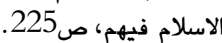

67. 67 إريك براور، يهود كوردستان. ص215.

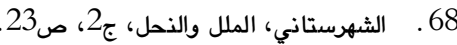

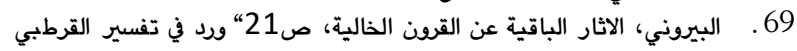

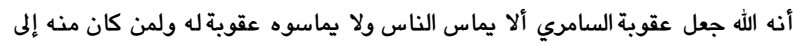

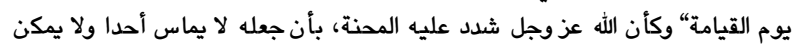

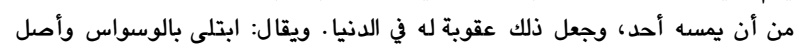

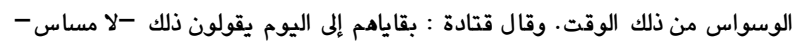

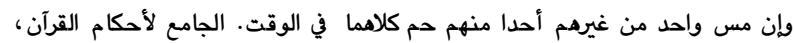

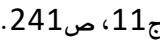
70.

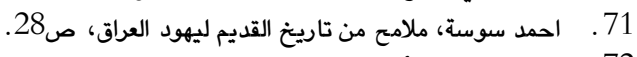

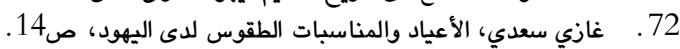

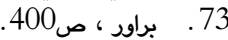

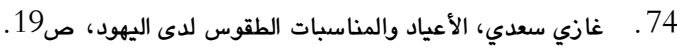

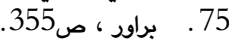

76. إباد هاشم الصاحب، السامريون الاصل والتاريخ والعقيدة والشريعة واثر

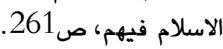

77. . إريك براور، يهود كوردستان. ص327. 78. إباد هاشم الصاحب، السامريون الاصل وردئ والتاريخ والعقيدة والشريعة واثر 79. الاسلام فيهم، ص262.

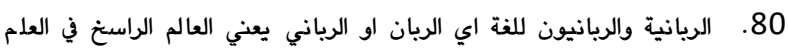

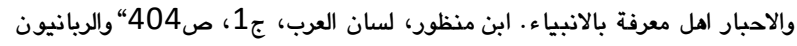

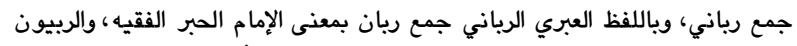

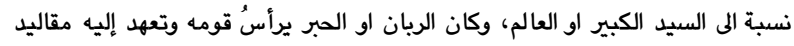

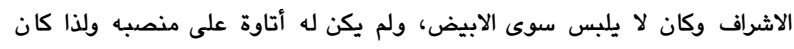

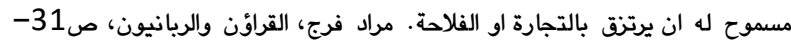

81. الفصل في الملل والاهواء والنحل،ج1،صو178، بذل المجهود في افحام

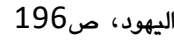

83.

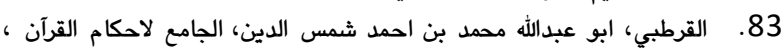

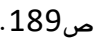

84. ثورة المكابين: هي حركة سياسية دينية يهودية، قادها في القرن الثاني قبل

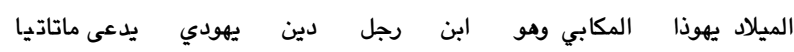

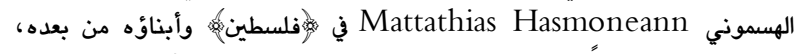

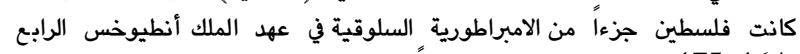

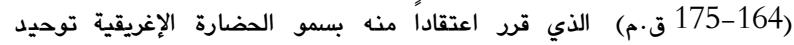

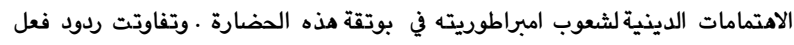

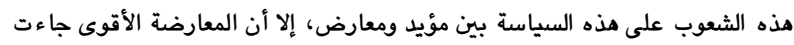

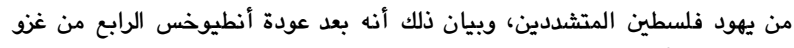

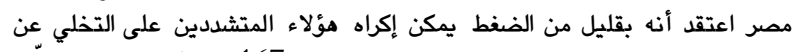

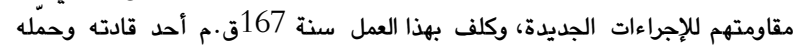

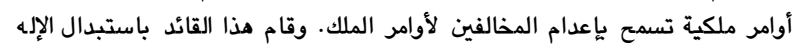

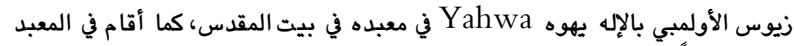
نفسه مذبحاً على النمط الإغريقي وحرّم ختان الذكور وكذلك امتلاك الأسفار المقدسة 
127. الاتحاد الصهيوني منظمة صهيونية تاسست عام 1918 في طهران برئئاسة

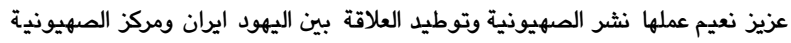

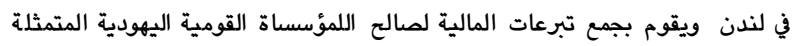

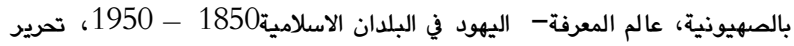
صموئيل اتينجر ص عالم المعرنة 119

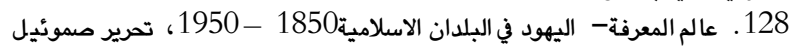

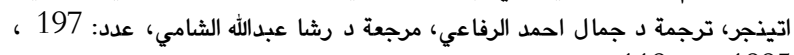

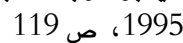

129. بذل المجهود في افحام اليهود، ص 1985

130. عالم المعرفة- اليهود في البلدان الاسلامية 1850 1980 -1950، تحرير صموئيل

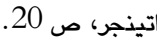

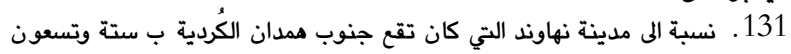

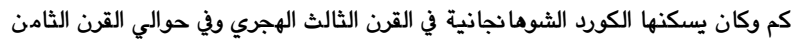

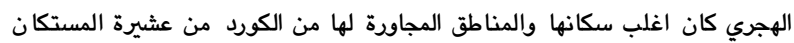

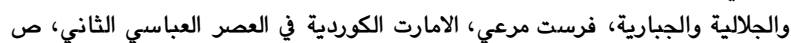
.50-49

http://www.jewishencyclopedia.com/arti .132 cles/2979-benjamin-ben-moses-nahawendi.

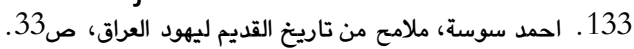

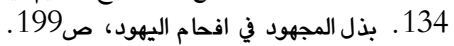

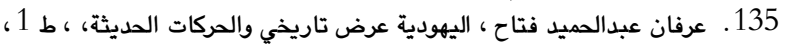

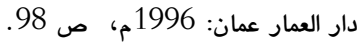
136 ـإريك براور، يهود كوردستان، ص 300 ـان.

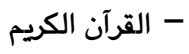

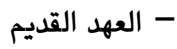

\section{7. قائمة المصادر والمراجع}

1.7

الأصطخري: أبو اسحاق إبراهيم بن محمد الفارسي المعروف بالكرخي (ت:

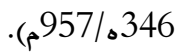

المسالك والممالك، الناشر دار صادر، بيروت: 2004م. البيروني: ابي الريحان محمد بن الحمد البيروني الخوارزمي

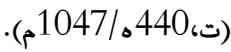

الاثار الباقية عن القرون الخالية، المانيا، لايبزغ: 1876م.

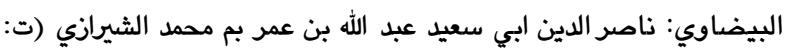

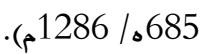
1. أنوار التنزيل وأسرار التأويل (دار الفكر، بيروت: د/ت).

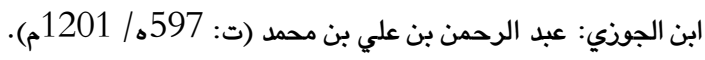

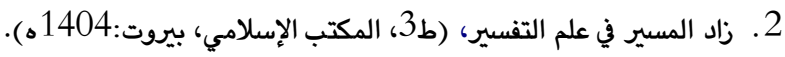

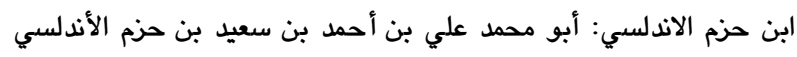

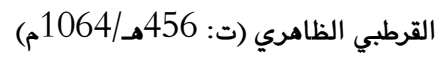

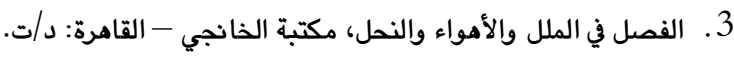

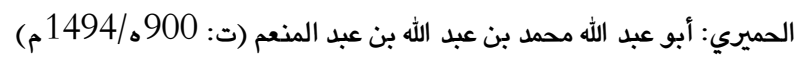

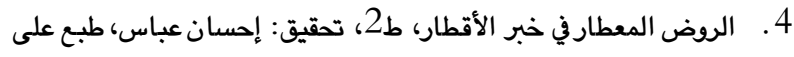

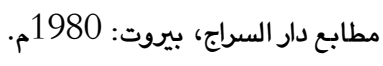
التطيلي: بنيامين بن بونا التطيلي

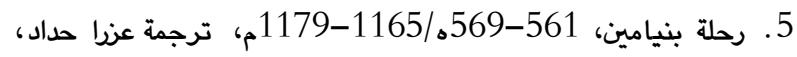
دراسة وتقديم عبدالرحمن عبدالله شيخ،ط1، المجمع الثقافي، الأمارت العربية المتحدة - ابوضبى: 2001.

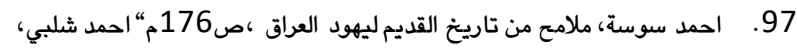

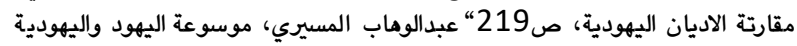

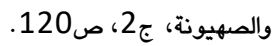
98. امارة حدياب وهي الامارة التي وجدت في منطقة الاشور القديمة في فترة الدولة

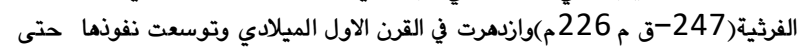

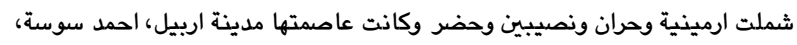

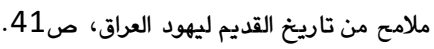

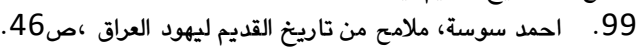

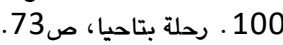

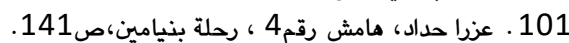

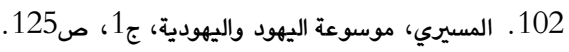

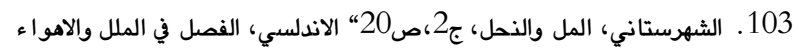

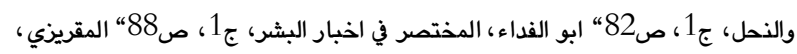

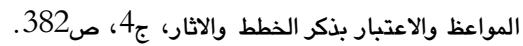

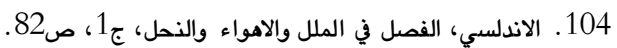

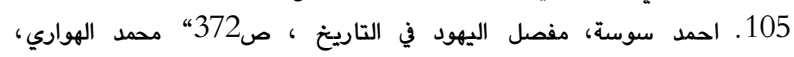

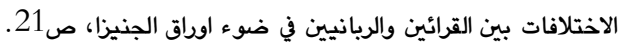

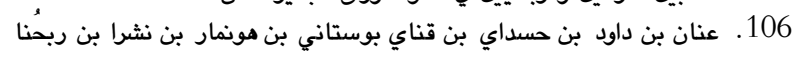

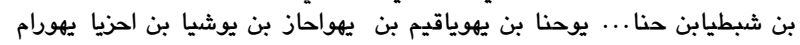

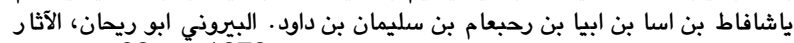

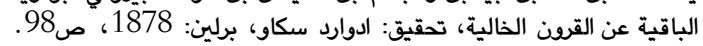

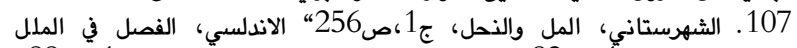

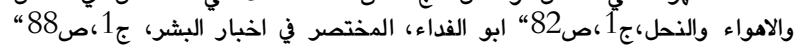

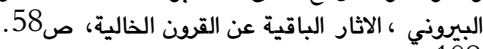

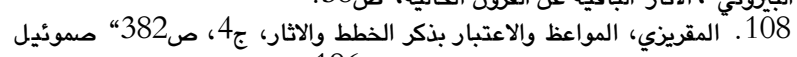

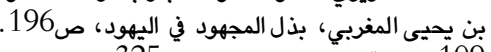

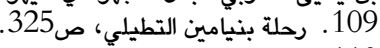

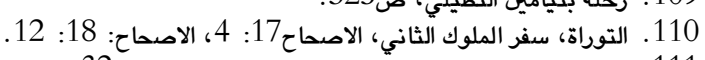

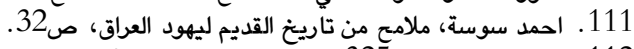

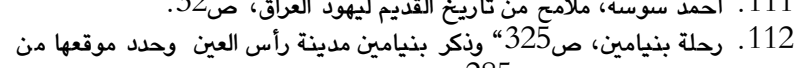
بلاد مادي. رحلة بنيامين، ص285.

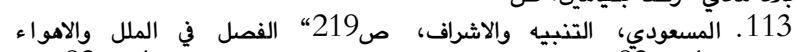

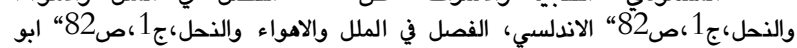

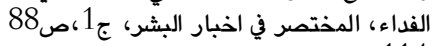

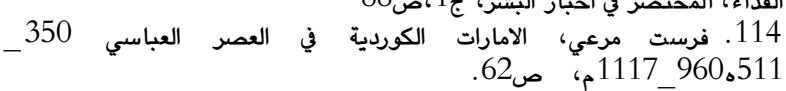

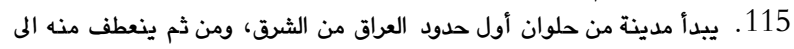

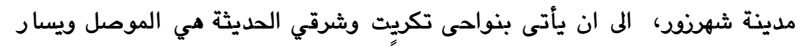

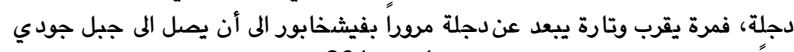

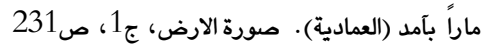

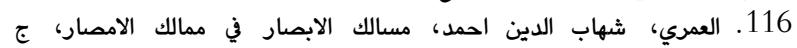

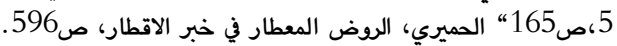

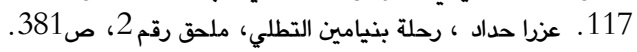
http://www.jewishencyclopedia.com/articl 118 es/1460-anan-ben-david

119. فرست مرعي، دراسات في تاريخ اليهودية والمسيحية في كُدستان، ص 27.

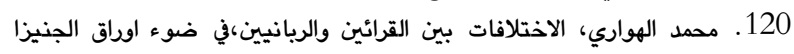

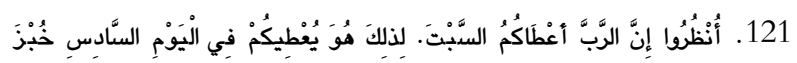

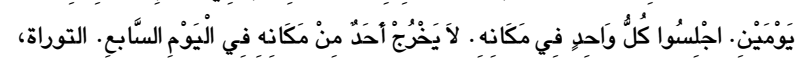

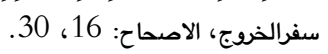

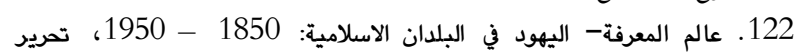
صموئيل اتينجر، ترجمة: جمال الحمة الحمد الرفاعي، مراجعة: الاسلامية: رشا عبدالله الشامي، العدد:

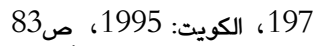

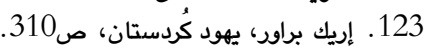

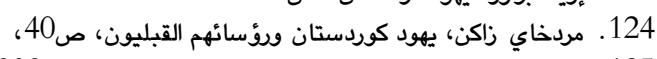

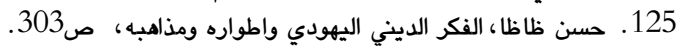

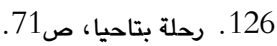


المقريزي: أحمد بن علي بن عبد القادر، أبو العباس الحسيني العبيدي، تقي الدين (ت 845هـ/ المقريزي آحمد بن علي بن عبدم) 21. المواعظ والاعتبار بذكر الخطط والآثار، ط1 أد دار الكتب العلمية، بيروت:

ابن منظور: محمد بن مكرم بن علي أبو الفضل، جمال الدين ابن منظور

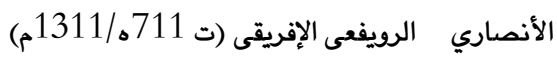

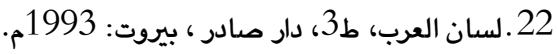

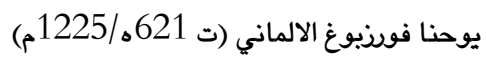
23.وصف الاراضي المقدسة في فلسطين، ط1، تحقيق: سعيد عبدالله

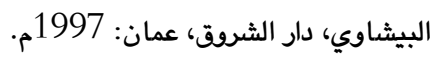
يوسيفوس بن كربون اليهودي 24.تاريخ يوسيفوس اليهودي، المطبعة العلمية، بيروت: دات.

2.7

اسلام خان: ظفر

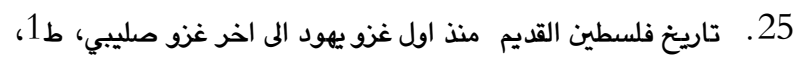
دار النائس، بيروت: 1973م. ايبش: احمد 26. التلمود كتاب اليهود المقدس تاريخه وتعاليمه ومقتطفات من

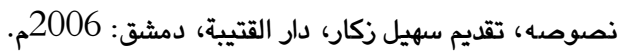
بابا: يوسف 27. القوش عبر التاريخ، مطبعة واوفست المشرق، بغداد:1979. بروار: ايرك 28. يهود كردستان، اكمله واصدره رفائيل بتاي، ترجمة شاخوان

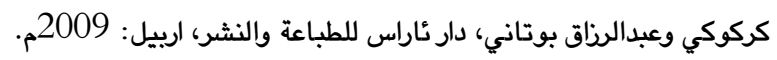
جلبي: احمد جلبي 29. مقارنة الاديان - اليهودية، ط2، مكتبة النهضة المصري، القاهرة:

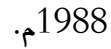
حداد: عزرا حداد 30. ملحقات كتاب رحلة بنيامين التطيلي، ترجمة عزرا حداد، دراسة

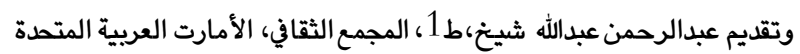
- ابوضبى: زاكن: مردخاي زاكن 31. يهودُ كُردستان ورؤسائهم القبليون، ترجمة دـ سعاد محمد خضر، مرجعة د عبدالفتاح بوتاني و د فرست مرعي، مؤسسة زين، كُردستان،

$$
\text { سليمانية: دـ/ت. }
$$$$
\text { سوسة: احمد }
$$

34. ملامح تاريخ يهود العراق، مؤسسة العربية للنشر، بيروت: 2001م.

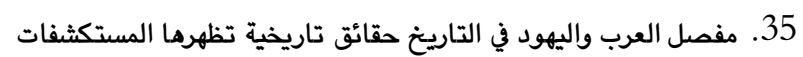

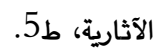

$$
\text { الصاحب: إباد هيشام محمود }
$$

36. السامريون الأصل والتاريخ ، والعقيدة والشريعة وأثر البيئة الأسلامية فيهم،مكتبة دنديس، الأردن: السامرنون الاصل والتاربخ، والعقدة والشرم
ابن حوقل: محمد بن حوقل البغدادي الموصلي، أبو القاسم (ت: بعد

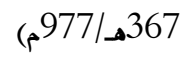

6. صورة الأرض، دار صادر، أفست ليدن، بيروت: 1938م.

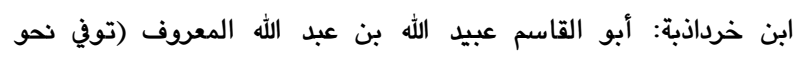

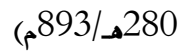
7. المسالك والممالك، دار صادر أفست ليدن، بيروت : 1889م.

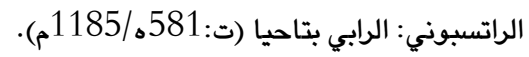

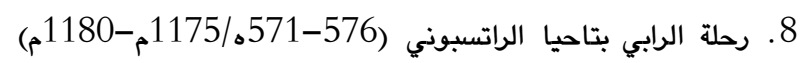
ترجمة وتحقيق: فؤاد عبد الرحيم دويكات، دار الكتاب الثقافية، الاردن: 2010 م. الشهرستاني: أبو الفتح محمد بن عبد الكريم بن أبى بكر أحمد الشهرستاني (ت 548هـ/1153)

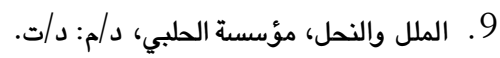

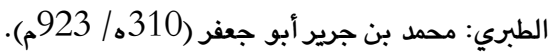

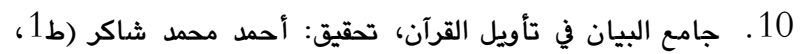
مؤسسة الرسالة، د/م: 2000م).

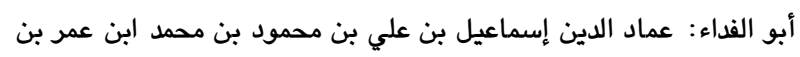

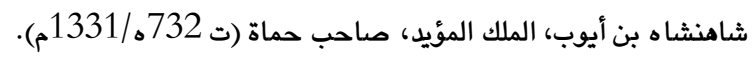
11.المختصر في أخبار البشر، ط1، المطبعة الحسينية المصرية، مصر: د/ت.

ابن فضل الله العمري: أحمد بن يحيى بن فضل الله القرثي العدوي العمري،

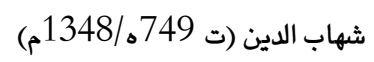
12. مسالك الأبصار في ممالك الأمصار، ط1، الدار) المجمع الثقافي، أبو ظبي: القزويني: زكريا بن محمد بن محمود (ت 682هـأ13/ 1283م)

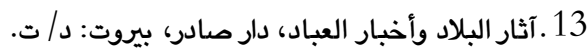

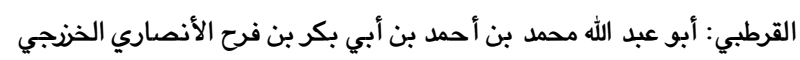
شمس الدين (ت 671هـ/ 1272 1272م). 14.الجامع لأحكام القرآن المعروف ب تفسير القرطبي، تدقيق: هشام سمير

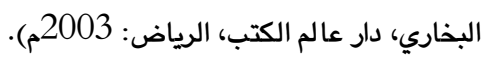

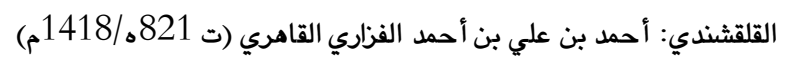

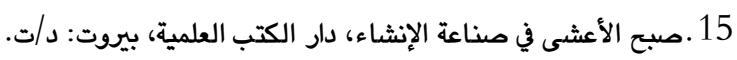

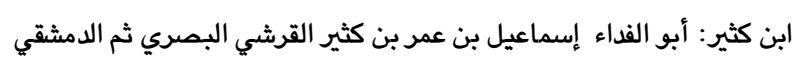

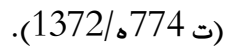

16.تفسير القرآن العظيم، تحقيق: سامي بن محمد سلامة (ط2، دار طيبة للنشر والتوزيع: 1999م). الكلدي: أبو بكر بن احمد ابن وحشي النبطي الكلدي

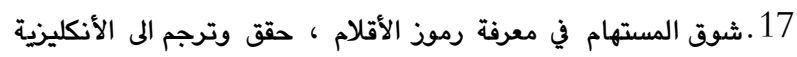
جوسيف مامر، لندن: 1804م.

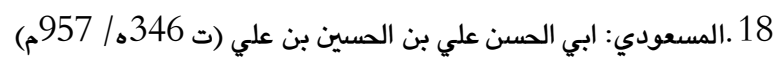
19 .التنبيه والإثراف، (مطبعة بريل، ليدن: 1893 1893م).

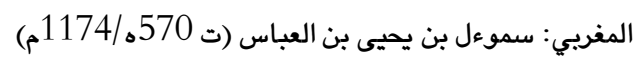

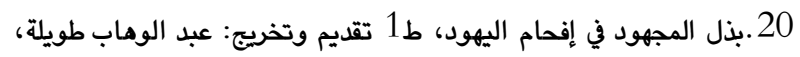

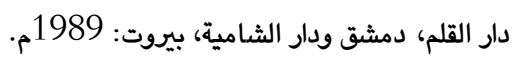


48. تاريخ الامارات الكُردية في العصر العباسي الثاني(350-560/511-

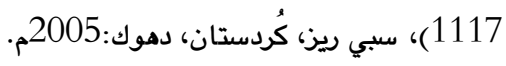
مرمورة: قيس الياس مرمورة

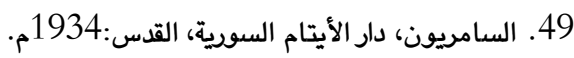

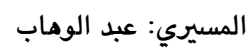

50. موسوعة اليهود واليهودية والصهيونية، الموجزة في جزئين، ط3، دار

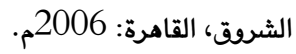$$
\text { نخبة من المؤلفين }
$$

51. قاموس كتاب المقدس، من من منشورات مطبعة شركة

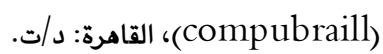

$$
\text { الهواري:محمد الهواري }
$$

52. الأختلافات بين القرائين والريانيين في ضؤ اوراق جنيزا، دار الزهرة،

$$
\text { القاهرة:1414هـ / 1994م. }
$$

53. اليهودية واليهود بحث في ديانة اليهود وتاريخهم ونظاههم الاجتماعي

والاقتصادي، ط23، دار نهضة مصر اليهرد للطبع والنشر، القاهرة: 1981.

$$
\text { ويكرام: آدكار. تي. اي .ويكرام }
$$

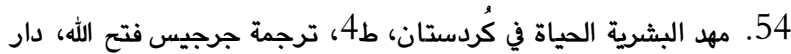

$$
\text { ئاراس للطباعة والنشر، كُودستان، اربيل:2010م. }
$$

$$
3.7 \text { المصادر الإنكليزية: }
$$

http://www.jewishencyclope dia.com/articles/1460anan-ben-david ,my father paradise $\mathrm{p} 14$, Printed in the U.S.A. .56 ariel sabar New York ; 2008.

$$
\text { مردخاي يونا } 4.7 \text { المصادر العبرية: }
$$$$
\text { 57. إنسكلوبيديا شيل يهود كرُدستان (ط1، أورشليم: 2003). }
$$

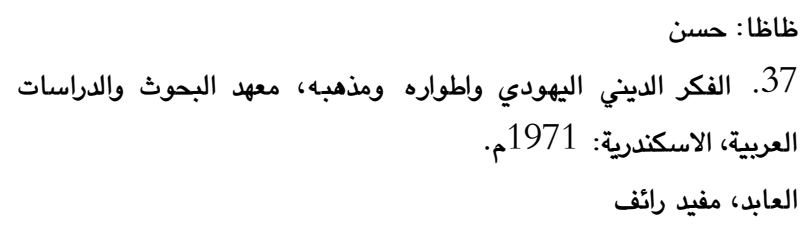

38. سورية في عصر السلوقيين، دار شمال للطباعة، دمشق: 1993. عبودي: هنري س 39. معجم الحضارة السامية، ط2، جروس برس، طرابلس لبنان: 1991م. غنيمة: يوسف رنق الله 40. نزهة المشتاق في تاريخ يهود العراق، ط1، مطبعة الفرات بغداد:

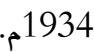
فتاح: عرفان عبدالحميد 41. اليهودية عرض تاريخي والحركات الحديثة، ط1، دار العمار، عمان: 1996 فرج: مراد 42. القرائون والريانيون، مطبعة الغرائب مصر، القاهرة: 1918م.

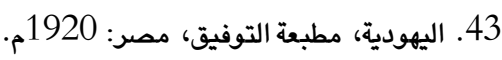
فكري: انطونيوس 44. تفسير التوراة، كنيسة السيدة العذراء بالفجالة في القاهرة، القاهرة: د /ت. قاسم: عبدة 45. اليهود في مصر من الفتح العربي الى الغزو العثماني، مؤسسسة العربية للنشر، مرعي: فرست 46. أدعياء المسيحانية في العصر الاسلامي - حركة داود الروحي العمادي نموذجاً، بحث منشور في مجلة كلية التربية الأساسية، جامعة بابل، العدد العدان (7)، شهر ايار، لعام 2012. 47. لمدات من تاريخ اليهودية والنصرانية ومخططاتها ضد الاسلام، ط2، لـام،

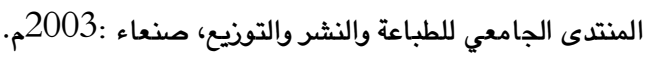




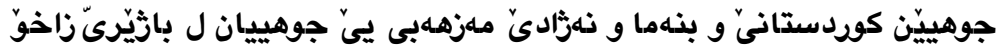

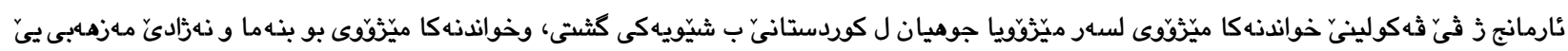

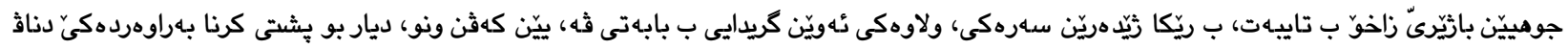

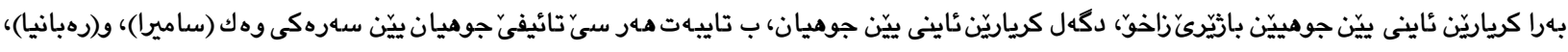

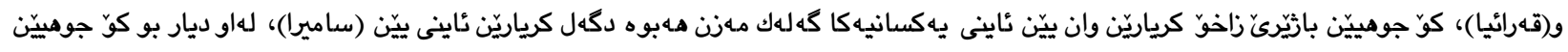

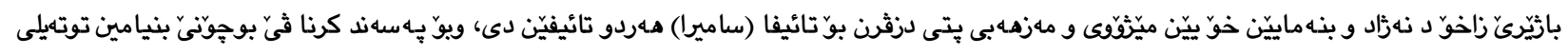

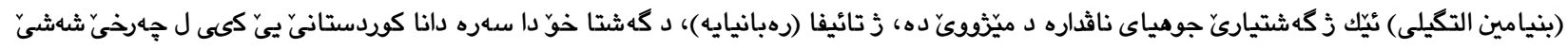

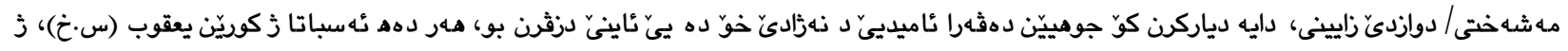

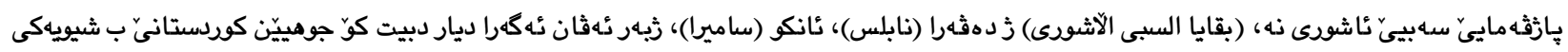
كثتى ذزومييّن ساميرا نه.

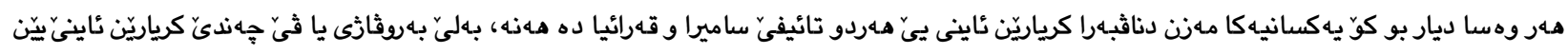

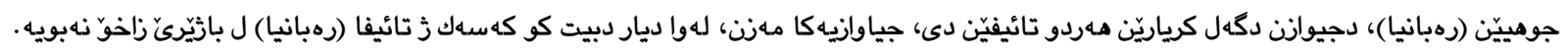

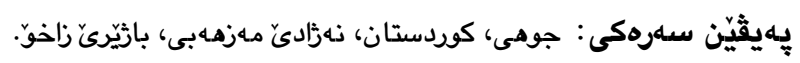

\section{Jews of Kurdistan and the Doctrinal Origins of the Jews of the City of Zakho}

\begin{abstract}
:
The research cares to study the history of Jews existence in Kurdistan in general, and studying the doctrine origin of Zakho Jews people particular, through returning to the source and reference specialized in this subject whether old or new, where through making comparis ons between the religious activities of Zakho Jews people and other Jews people especially the three main sect (Samarian, Rabbincall, Karaism ), it shows that the Jews of Zakho have practiced some religious ritual very similar to what the Samarian sect practiced rather than the two other sects rabbincall, Karaism, it is preferred largely that the Jews of Zakho belong in their historical and doctrine origins to the Samarian sect and what emphasized this view is that Benjamin of Tudela one of the Jewish traveler from Rabbincall sect, who visited Kurdistan in 600 A.H - 1200 A.D. he mentioned that the Jews of al Amadian city are belong to the ten remaining tribes of Assyrian captivity, who have been brought from Nablus, so it may be inferred that the Jews of Kurdistan in general are from the Samarian Jews, there is also some kind of similarity between the religious ritual of the two sects Samarian and Karaism, while the rabbincall sects is different from both two sects, where it was not noticed any existence of Jews that belong to these two sects in the Zakho.
\end{abstract}

Keywords: Jews ، Kurdistan ‘ Doctrinal Origins ‘ Zakho City . 